\title{
Gas hydrate quantification at a pockmark offshore Norway from joint effective medium modelling of resistivity and seismic velocity
}

\author{
Eric Attias ${ }^{a b}$, Kelvin Amalokwu ${ }^{c}$, Millie Watts ${ }^{a}$, Ismael Himar Falcon-Suarez $^{d}$, Laurence North $^{d}$, Gao Wei Hu ${ }^{f}$, \\ Angus I. Best ${ }^{d}$, Karen Weitemeyer ${ }^{a e}$ and Tim A. Minshull ${ }^{a}$ \\ ${ }^{a}$ Ocean and Earth Science, National Oceanography Centre Southampton, University of Southampton, Southampton, UK. \\ ${ }^{b}$ Hawai' $i$ Institute of Geophysics and Planetology, School of Ocean and Earth Science and Technology, University of Hawai'i at Mãnoa, \\ Honolulu, USA. \\ ${ }^{c}$ University of Texas at Austin, Jackson School of Geosciences, Texas, USA. \\ ${ }^{d}$ National Oceanography Centre, University of Southampton Waterfront Campus, Southampton, UK. \\ ${ }^{e}$ Ocean Floor Geophysics, BC, Canada. \\ ${ }^{f}$ Qingdao Institute of Marine Geology, Qingdao, China.
}

\begin{abstract}
Methane emissions from gas hydrate deposits along continental margins may alter the biogeophysical properties of marine environments, both on local and regional scales. The saturation of a gas hydrate deposit is commonly calculated using the elastic or electrical properties measured remotely or in-situ at the site of interest. Here, we used a combination of controlled-source electromagnetic (CSEM), seismic and sediment core data obtained in the Nyegga region, offshore Norway, in a joint elastic-electrical approach to quantify marine gas hydrates found within the CNE03 pockmark. Multiscale analysis of two sediment cores reveals significant differences between the CNE03 pockmark and a reference site located approximately $150 \mathrm{~m}$ northwest of CNE03. Gas hydrates and chemosynthetic bivalves were observed in the CNE03 sediments collected. The seismic velocity and electrical resistivity measured in the CNE03 sediment core are consistent with the P-wave velocity $\left(V_{P}\right)$ and resistivity values derived from seismic and CSEM remote sensing datasets, respectively. The $V_{P}$ gradually increases $(\sim 1.75-1.9 \mathrm{~km} / \mathrm{s})$ with depth within the CNE03 pipe-like structure, whereas the resistivity anomaly remains $\sim 3 \Omega \mathrm{m}$. A joint interpretation of the collocated seismic and CSEM data using a joint elastic-electrical effective medium model suggests that for the porosity range 0.55-0.65, the gas hydrate saturation within the CNE03 hydrate stability zone varies with depth between 20 and $48 \%$. At 0.6 porosity, the hydrate saturation within CNE03 varies between $\sim 23$ and $37 \%$, whereas the weighted mean saturation is $\sim 30 \%$. Our results demonstrate that a well-constrained gas hydrate quantification can be accomplished by coupling P-wave velocity and CSEM resistivity data through joint elastic-electrical effective medium modelling. The approach applied in this study can be used as a framework to quantify hydrate in various marine sediments.
\end{abstract}

Keywords: Gas hydrate, Marine CSEM, Seismic velocity, Effective Medium Modelling

\section{Introduction}

Hydrate-bearing sediments at continental margins and permafrost regions contain methane volumes comparable to global fossil fuels reserves (Collett, 2002, Milkov and Sassen, 2002, Milkov, 2004, Klauda and Sandler. 2005. Pinero et al. 2013, Boswell et al., 2015). The environmental and economic implications of methane lead to a growing need for efficient and reliable methods for gas hydrate deposits quantification (Collett et al., 2009; Ruppel, 2011, Boswell et al., 2014; Marín-Moreno et al., 2015; Collett and Boswell, 2012, Li et al., 2016). Direct and accurate quantification of gas hydrate using pressure core sampling may lead to equivocal interpretations, due to uncontrolled core recovery-induced hydrate dissociation, gas expansion, and exsolution effects (e.g., Milkov et al., 2004, Holland et al. 2008; Collett et al. 2008). Sonic velocity and electrical resistivity data obtained from well-log measurements are

${ }^{*}$ Corresponding author: Dr. Eric Attias: attias@hawaii.edu 
conventionally used to estimate hydrate saturation (e.g., Pearson et al. 1983, Hyndman et al., 1999: Collett and Ladd, 2000: Collett and Boswell, 2012). However, well-log operations are technically complex, expensive, and only provide localized information (Collett et al., 1998, Hyndman et al. 1999, Collett and Ladd, 2000; Riedel et al., 2006). Gas hydrate saturations within a single reservoir unit could vary significantly (e.g., Torres et al., 2008; Malinverno et al. 2008; Riedel et al., 2009); thus, localized pressure cores and well-log measurements may not adequately represent large-scale hydrate reservoirs.

In contrast, remote sensing methods such as marine controlled-source electromagnetic (CSEM) and seismic surveys provide regional data, enable larger scale detection, delineation and potential quantification of gas hydrate deposits (e.g., Singh et al., 1993, Wood et al., 2000, Lodolo et al., 2002, Lee et al., 2005, Weitemeyer et al., 2006, Schwalenberg et al. 2010; Attias et al. 2016). Coincident well-log data can calibrate the data acquired using these remote sensing techniques. Electrical resistivity measured by CSEM provides information about the pore fluids properties and distribution, complementary to structural information obtained from seismic data. Thus, a joint interpretation of coincident seismic and CSEM data enhance the characterisation of gas hydrate deposits (Attias et al., 2016, Goswami et al. 2017, Schwalenberg et al. 2017). However, such joint elastic-electrical approaches require a suitable rock physics framework to constrain the elastic-electrical parameters and link them to petrophysical properties of the reservoir (e.g., Du and MacGregor, 2010, Han et al. 2011b, 2016).

The elastic and electrical properties of sediments are predominantly controlled by parameters such as mineralogy, porosity, pore-fluid and saturation, grain shape/alignment, and temperature (e.g., Ellis et al. 2010). In order to fully exploit the elastic and electrical properties of rocks, both property responses should be linked by a common microstructure. Effective medium methodologies can be used to derive the joint bulk elastic and electrical properties of microheterogeneous sedimentary rocks (e.g., Sheng, 1990, 1991; Berryman, 1992; Hornby et al., 1994; Carrara et al., 1994, Jakobsen et al., 2000, Carcione et al., 2007). In this study, "microheterogeneous" refer to different constituents composite and their configurations, as explained in section 5.1 The effective medium models are based on first-principle physics, where the effective properties of a composite are derived from the properties of its individual constituents (e.g., quartz, clay, calcite, etc.) and their arrangements, giving an idea of the topology of the medium.

In this work we employ an effective modelling scheme based on a combination of the self-consistent approximation (SCA) (e.g., Hill, 1965, Te Wu, 1966) and the differential effective medium (DEM) (e.g., Cleary et al., 1980, Berryman, 1992) theories. A detailed motivation for this approach is given by Sheng (1990), who was the first to introduce this concept. Sheng (1990) showed that the combined SCA/DEM method reproduces the microstructural feature of bicontinuity of phases in sedimentary rocks at any finite porosity, which implies the existence of fluid pathways. This approach has been used with success in modelling bulk elastic properties of shales (e.g., Hornby et al., 1994), hydrate-bearing sediments (e.g., Jakobsen et al. 2000; Chand et al., 2006, Ghosh et al., 2010), and the joint elastic-electrical properties of clay-bearing sandstones (e.g., Han et al., 2011a).

Although effective medium theories have been used for modelling the elastic properties of hydrate-bearing sediments, a joint elastic-electrical effective medium modelling approach has not been applied for hydrate estimation, to the best of our knowledge. Here, we model the joint elastic-electrical properties of clay-rich, hydrate-bearing sediments by extending the modelling approach of Han et al. (2011a). Detailed analysis of sediment cores from a gas hydrate pipe-like structure and an adjacent reference site provided us with (i) physical evidence for the existence of gas hydrate at the site of interest, (ii) localized porosity, elastic, and electrical properties, and (iii) Characterisation of the lithology in three different length scales: macro, meso, and micro. We used the information obtained from these cores for the model inputs and to confirm the background sediment resistivity and velocity values (from seismic and CSEM data) used for calibration of the effective medium model. This approach helped us to constrain many of the model input parameters. The resulting joint elastic-electrical effective medium model was then applied for hydrate quantification using seismic and CSEM datasets from our study region, which were previously analysed by Plaza-Faverola et al. (2010) and Attias et al. (2016), respectively.

We note that for our study region, there is evidence suggesting that the gas hydrate forms in pore-filling, fracturefilling, or a combination of both (e.g., Westbrook et al. 2008a, Plaza-Faverola et al., 2010). For fracture-filling hydrate, a rigorous effective medium modelling is beyond the scope of this paper. However, because limited electrical anisotropy detected by CSEM inversions at the site of interest (Attias et al. 2016) precludes the presence of hydrate in strongly aligned fractures, we can make the following approximation: If fractures are randomly oriented and we are averaging over large volumes, then the fracture-filling can be treated as pore-filling (with the fractures being the pores) but with a lower aspect ratio (i.e. effective medium). For pore-filling hydrate, we take the analysis further by 
applying a fully rigorous effective medium modelling scheme (sections 5.1,5.2, and 6.2,6.4).

Our case study focuses on the CNE03 pockmark (Fig. 11). This pockmark has a Type-2 morphology, according to the classification system of Sultan et al.(2010); Riboulot et al.(2011,2016). A Type-2 pockmark is defined as complex seafloor morphology underlain by irregular pipe-like structure, which is primarily controlled by the formation and decomposition of gas hydrate. The CNE03 pockmark is underlain by an irregular pipe-like structure that is $\sim 200 \mathrm{~m}$ in diameter at the seabed and $\sim 500 \mathrm{~m}$ at the base of the gas hydrate stability zone (BGHSZ) (e.g., Bünz et al., 2003, Plaza-Faverola et al., 2010).

\section{Geologic Setting}

The Norwegian Marginal Sea is located northwest of Norway, bound by the North and Greenland Seas between $62^{\circ} \mathrm{N}, 5^{\circ} \mathrm{E}$ to $71^{\circ} \mathrm{N}, 25^{\circ} \mathrm{E}$ (Eastern flank); and $62^{\circ} \mathrm{N}, 6^{\circ} \mathrm{W}$ to $65^{\circ} \mathrm{N}, 13^{\circ} \mathrm{W}$ (Western flank). The Norwegian continental margin encompasses the Nyegga region (Fig. 1, inset map), which is positioned NW of the Storegga slide between the Vøring and Møre sedimentary basins, extending over $200 \mathrm{~km}^{2}$ (e.g., Bünz et al., 2003; Brekke, 2000). The Nyegga region lies in water depths of $\sim 700-800 \mathrm{~m}$, with a seabed slope angle of $\sim 1^{\circ}$ (Hovland et al., 2005, PlazaFaverola et al. 2010). Both the Nyegga and Storegga regions show sediment compaction patterns with varying thicknesses, resulting from glacial-interglacial climate cycles (e.g., Dahlgren et al., 2002; Kjeldstad et al., 2003). The Miocene / Early Pliocene Kai and the Plio / Pleistocene Naust sediment Formations (e.g., Dalland et al., 1988, Eidvin et al., 1998) host the Nyegga and Storegga gas hydrate systems (e.g., Bünz et al., 2003; Berndt et al., 2003, Westbrook et al. 2008a; Senger et al. 2010). The Kai Formation sediment consists of fine-grained hemipelagic oozes, whereas the Naust Formation is characterised by sharp lithological fluctuations resulting in debris flow deposits and hemipelagic sediments (Bünz et al., 2003; Hustoft et al., 2007).

Elongated northwards, approximately $240 \mathrm{~km}$ long and $60 \mathrm{~km}$ wide, the Helland-Hansen Arch anticline lies beneath Nyegga (e.g., Kjeldstad et al., 2003). This anticline has enabled upwards thermogenic gas propagation from deep hydrocarbon-rich reservoirs, promoting fluid expulsion which disrupted the seabed homogeneity by forming an extensive pockmark field along the Nyegga region (Judd and Hovland, 1992; Bouriak et al., 2000; Hovland et al., 2005, Hovland and Svensen, 2006, Plaza-Faverola et al., 2010). These pockmarks are underlain by pipe-like structures, caused by the vertical movement of fluids and gas (e.g., Bouriak et al., 2000; Berndt et al., 2003; Plaza-Faverola et al., 2011). Nyegga's pipe-like structures accommodate gas hydrates in a low saturation state, with an estimated mean volume of $710 \mathrm{GSm}^{3}\left(\mathrm{GSm}^{3}=10^{9}\right.$ standard cubic metres), which is equivalent to $\sim 4,500$ million barrels of oil (Senger et al., 2010). One of Nyegga's pipe-like structures is the CNE03 pockmark, which is thought to contain moderate-to-high concentration of hydrates that either forms in sub-vertical veins, subsequent to vertical migration of thermogenically-sourced gas into the hydrate stability zone (Plaza-Faverola et al. 2010); or/and forms in a pore-filling morphology, particularly near the BGHSZ as previously indicated for this region (e.g., Westbrook et al., 2008a; PlazaFaverola et al. 2010). At its centre, the CNE03 pipe-like structure presents intense seismic scattering and attenuation and is bounded by the pull-up of reflectors in its margins (Ivanov et al., 2010; Plaza-Faverola et al., 2011, 2012). The CNE03 pockmark is covered by glacial-interglacial silty clay hemipelagic sediments (e.g., Bünz et al. 2003, Ivanov et al., 2010).

\section{Data and Methods}

\subsection{Seismic and CSEM Data}

Seismic and CSEM surveys conducted at the CNE03 pockmark provided data for a comprehensive analysis of the elastic and electrical properties of this pockmark. In brief, Plaza-Faverola et al. (2010) constructed a P-wave velocity $\left(V_{P}\right)$ model using TomoInv, a reflection time tomography software (Delbos et al., 2001, 2006). Their model shows that the $V_{P}$ within the CNE03 pipe-like structure ranges between $\sim 1.6$ and $1.9 \mathrm{~km} / \mathrm{s}$ (Fig. 2a), collocated with a columnar seismic blanking zone (CSBZ) that is often associated with the presence of hydrates (e.g., Riedel et al., 2002; Boswell et al., 2015). Adjacent to the CNE03 pipe structure (200 m north of CNE03), the background velocity ranges between $\sim 1.6$ and $1.7 \mathrm{~km} / \mathrm{s}$. The velocities in the upper part of the seismic tomography model $(<1.7 \mathrm{~km} / \mathrm{s}$ between 0-80 meters below seafloor) are poorly constrained, due to low ray coverage (Plaza-Faverola et al., 2010). Within the CNE03 pipe-like structure, between 80 meters below seafloor (mbsf) and 280 mbsf (BGHSZ), the $V_{P}$ 
gradually increases. For comparison with our effective medium model, we divided this varying $V_{P}$ into three depth intervals and averaged the values of each region, yielding velocities of $1.75 \mathrm{~km} / \mathrm{s}\left(V_{P_{1}}\right), 1.83 \mathrm{~km} / \mathrm{s}\left(V_{P_{2}}\right)$, and $1.9 \mathrm{~km} / \mathrm{s}$ $\left(V_{P 3}\right)$ for depth intervals of 80-180, 180-200, and 200-280 mbsf, respectively (Fig.221).

Attias et al. (2016) delineated the resistivity structure beneath the CNE03 pipe-like hydrate accumulation (Fig.2p) using 2.5-D CSEM inversion constrained by the collocated seismic reflection and tomography information (Westbrook et al. 2008b, Plaza-Faverola et al., 2010, 2012). This CSEM inversion gave resistivity values of $\sim 3 \Omega \mathrm{m}$ within the CNE03 pipe-like structure, and a background resistivity of $\sim 1.3-1.5 \Omega \mathrm{m} 200 \mathrm{~m}$ north of CNE03, collocated with the background $V_{P}$ (Fig. 22). These resistivity values have been confirmed by 2.5-D CSEM inversions of a towed-receiver data (Attias et al. 2018). To be consistent with the $V_{P}$ data, we extracted the resistivity values observed between 80 and $280 \mathrm{mbsf}$ (Fig. 22). However, we found that the resistivity variations within this depth interval are insufficient to justify a different depth discretization as was done for the velocity model.

\subsection{Sediment Core Data}

Sediment cores were collected from within the CNE03 pockmark, and from a nearby reference site (i.e., regional background). To study the characteristics of a gas hydrate driven lithology. For Multiscale analysis, we discretized the sediment cores to three different scales - meter (Macro), centimetre (Meso) and sub-millimeter (Micro) scales.

\subsubsection{Macro-scale: Sediment Core Acquisition \& Petrophysical Measurements}

Sediment cores of $\sim 6.8 \mathrm{~m}$ and $\sim 8 \mathrm{~m}$ length were recovered from the CNE03 pockmark and a background site, respectively, using a piston corer. The background site is located $\sim 150 \mathrm{~m} \mathrm{NW}$ from the CNE03 pockmark (Fig. 11), and hence represents undisturbed sediments for comparison with hydrate-bearing sediments. Both sediment cores were immediately split after collection into $1.25 \mathrm{~m}$ length sections (15 in total) and stored at $5^{\circ} \mathrm{C}$. A macro-scale analysis was performed using all sediment sections. First, the core sections were measured for petrophysical properties (P-wave velocity, electrical resistivity, gamma density, magnetic susceptibility) using the Geotek Multi-Sensor Core Logger (MSCL-S) (Weaver and Schultheiss, 1990; Weber et al., 1997). Second, the cores were split vertically, imaged using Geotek's Core Imaging System (MSCL-CIS), classified into four major lithofacies and visually logged.

\subsubsection{Meso-scale: Laboratory Measurements of Elastic and Electrical Properties}

We measure the elastic and electrical properties of the sediment cores on a meso-scale, using six and four cylindrical fully saturated samples ( $5 \mathrm{~cm}$ wide and $2 \mathrm{~cm}$ length), as extracted from the background and CNE03 core sections, respectively, at varying depths (Figs 3 a and c). The resulting samples were slightly confined $(0.2 \mathrm{MPa}$ ) in a pressure cell, to improve device-sample coupling. Ultrasonic $V_{P}$ and electrical resistivity were then measured. $V_{P}$ was measured using the pulse-echo technique (McCann and Sothcott, 1992), which provides useable frequencies between 300 and $1000 \mathrm{kHz}$ with absolute accuracies of $\pm 0.3 \%$ for velocity (Best, 1992). We use here the $V_{P}$ values at a single frequency of $600 \mathrm{kHz}$, obtained from Fourier analysis of broadband signals.

For the electrical resistivity tomography (ERT), we measured the electrical resistivity using 16 stainless steel electrodes, distributed radially in two rings around the sample. The sixteen resistivity measurements were taken using $0.5 \mathrm{~mA}$ of alternating current at a frequency of $80 \mathrm{~Hz}$, then averaged to yield a single resistivity value per each sample. Thirteen consecutive measurements are made with all offset electrode pairs, resulting in a total of 208 measurements. The ERT data were inverted using an isotropic finite element algorithm, to derive the resistivity distribution from the measured voltage (North et al., 2013). The accuracy of this measurement is $\pm 5 \%$, for samples with electrical resistivity range of 1-100 $\Omega \mathrm{m}$ (North et al., 2013; , North and Best, 2014). All the elastic and electrical measurements were conducted at a temperature of $\sim 2^{\circ} \mathrm{C}$, in a laboratory with a controlled ambient temperature of $\sim 20^{\circ} \mathrm{C}$ and humidity of $55 \%$. The porosity was later calculated from weight differences between the saturated and oven-dried $\left(\right.$ at $\left.40^{\circ} \mathrm{C}\right)$ samples. The wet (macro-scale) and dry (meso-scale) porosity measurements are reasonably consistent, with comparable trends and very subtle differences that we attribute to local heterogeneities (Fig. 3p).

\subsubsection{Micro-scale: X-Ray Computed Tomography $(X-C T)$ scans}

To analyse the background and CNE03 sediment cores on a micro-scale, we performed CT scans using a GE Phoenix industrial X-CT. CT imaging can contribute to assessing grain size, density and porosity, and detect any presence of biota (e.g., Bin et al., 2013). For this purpose, $\sim 2 \mathrm{~mm}$ diameter samples from the top of each background 
and CNE03 core section (Figs $3 \mathrm{~B}$ and $\mathrm{c}$ ) were carefully extracted and placed in X-ray scanning tubes. The samples were scanned using $80 \mathrm{kV}$ and $120 \mu \mathrm{A}$, producing high-resolution $\sim 4 \mu \mathrm{m} \mathrm{X-CT} \mathrm{images.}$

\subsection{Micro-scale: X-ray Diffraction (XRD) Mesurements}

To characterise the mineralogy of the CNE03 sediment, we performed a series of X-ray diffraction (XRD) measurements. A semi-quantitative bulk mineral analysis from standards was undertaken using a least squares method similar to that used in FULLPAT (Chipera and Bish, 2002) and the Microsoft Excel-based programs RockJock (Eberl, 2003).

\section{Results}

\subsection{Sediment Core Analysis}

In general, the background core contained consistently pale brown foraminifera-rich sediment, whereas the CNE03 core exhibit a varied lithology of finely-grained ooze and coarse shell horizons (Figs 3 a and c). The background sediment represents a continuous hemipelagic sequence (Lithofacies B), containing variations in microfossils (no macrofossils observed) and lithic content consistent with slowly settled marine clays (Fig. 3a, Table 11). No hydrates or cavities were observed in the background core upon recovery (Fig. 33 a).

The CNE03 sediment varies from pale grey to green-grey, with sparse cavities (Fig. 36). During onboard core segmentation, visual observation revealed chunks ( $\sim 2 \mathrm{~cm}$ in length) of hydrates at the base of the CNE03 core (Figs 1, 3k), which decomposed via bubbling, similar to the dissociation of near-seabed hydrate accumulations recovered from within the CNE03 pockmark by Ivanov et al. (2007). Two shell horizons are observed within the CNE03 core (Fig. 44, hosting sporadic dark grey carbonate nodules. These horizons are marked by a gradual increase of the shell frequency, best observed in the X-ray images (Fig. 4p). The extracted shell (Figs 4 k and d) was identified as the chemosynthetic Isorropodon nyeggaensis sp. bivalve (Krylova et al., 2011), also referred to as $c f$. Calyptogena sp. (Ivanov et al. 2010). The Isorropodon nyeggaensis sp. bivalve belongs to the chemosymbiotic families, which metabolise organic substance via chemosymbiosis by hosting intracellular sulfide-oxidizing bacteria (e.g., Cavanaugh, 1983; Distel, 1998). The Isorropodon nyeggaensis bivalves were previously utilised as a model-dependent time marker for methane seepage in the Nyegga pockmark field, where sediment cores from a seep-related structure detected a $60 \mathrm{~cm}$ layer of Isorropodon nyeggaensis shells at $100 \mathrm{~cm}$ depth (Karstens et al. 2018). Thus, Isorropodon nyeggaensis sp. shell fragments retrieved from the $\mathrm{CNE} 03$ cores provides additional evidence for contemporary methane influx and subsequent hydrate formation within the $\mathrm{CNE} 03$ pipe-like structure.

The CNE03 core macro-scale measurements present a higher $V_{P}$ and resistivity values than the background core, whereas the porosity in both cores ranges between $\sim 0.55$ and $\sim 0.65$ (Fig. 33). The CNE03 $V_{P}$ macro-scale measurement is abrupt, segmented, and only extends to $\sim 2.2 \mathrm{mbsf}$ (Fig. 3b). The high $V_{P}$ observed in the CNE03 core between $\sim 1.5-2.2 \mathrm{mbsf}$ is attributed to a shell horizon, whereas below $\sim 2.2 \mathrm{mbsf}$ no $V_{P}$ measurement was obtained, most likely due to the presence of cavities (i.e., low-density), as shown in Fig. 3k. The higher macro-scale resistivity measurement of the CNE03 core in comparison to the background core (Fig. 3 b), is attributed to the freshening of pore water during hydrate dissociation on core recovery. The macro-scale resistivity measurement of the background core is comparable with a resistivity log obtained from a borehole located $\sim 24 \mathrm{~km} \mathrm{NW}$ of the CNE03 pockmark (Senger) et al. 2010). The background sediments are less disrupted than the CNE03 sediments, as indicated by the core images (Figs 3 a and c). We note that the macro-scale $V_{P}$ and resistivity values derived from both the background and CNE03 cores are comparable to the remotely-sensed $V_{P}$ and CSEM resistivity values (Figs 2 and 3 ).

The average porosity calculated from both the background and CNE03 macro-scale measurements is approximately 0.6 (Fig. 3b), consistent with a nearby well-log data (Hustoft et al., 2009). The Image of section A of the CNE03 core (Fig. 3.), shows two cavities that are attributed to the dissociation of pre-existing hydrate because at core recovery, gas hydrates occupied (Fig. 17) the cavity observed at $\sim 6.8 \mathrm{mbsf}$ (Fig. 3F). In-spite of these apparent cavities, the macro-scale porosity measurements obtained from the background and CNE03 sediment cores are comparable (Figs $3 \mathrm{~b}$ and c). The comparison of the two sediment cores demonstrates the distinct difference between undisturbed regional sediments and profoundly disturbed sediments beneath the CNE03 pockmark, that we attribute to methane flux into the GHSZ, the resulting hydrate formation process, and the presence of shells. 


\subsection{Electrical Resistivity Tomography}

Fig. 5 shows a comparison between the ERT of the background and CNE03 meso-scale samples, as retrieved from $\sim 6.8 \mathrm{mbsf}$. ERT of the background sample yields a relatively low and homogenous resistivity (Fig. 5 a) compared to the heterogeneous and higher resistivity observed in the CNE03 sample (Fig. $5 \mathrm{p}$ ). The resistivity of the background sample $(\sim 2-3 \Omega \mathrm{m})$ is consistent with the resistivity obtained from the macro-scale measurement (Fig. 3b). The relatively high resistivity $(\sim 3-6 \Omega \mathrm{m})$ observed in the CNE03 sample might be related to pore-water freshening from hydrate dissociation, or the presence of electrically resistive shells (Figs 3b,c, and 4), but most likely a combination of these two factors. This meso-scale ERT analysis supports the notion that the CNE03 core sample previously contained hydrates, which dissociated during core recovery.

\subsection{X-Ray Computed Tomography}

The X-CT scans illustrate the microstructure of the sediments obtained from the background and CNE03 microscale samples (Fig. 6). The background sample is relatively homogeneous, finely-grained and tightly compacted (Fig. 6a). The CNE03 sample is heterogeneous, and contain finely-grained ooze and coarse shell horizons (Fig. 6p). The CNE03 micro-scale sample shows a wide range of pore volumes (Fig. 6), presumably caused by the dissociation of pre-existing hydrates.

\subsection{X-ray Diffraction Analysis}

Our XRD analysis indicates that the dominant mineralogy in the core samples is clay, making up 55\% of the sediment composition, followed by $17.5 \%$ quartz and smaller concentrations of calcite, magnesium calcite and Kfeldspar (Table 2).

\section{Data Assessment using Effective Medium Modelling}

\subsection{Effective Medium modelling Approach}

Effective medium theories have been used widely and successfully to model the bulk response of a microheterogeneous composite (e.g., Sheng, 1990; Ellis, 2008, Han et al., 2011a). Although effective medium theories do not incorporate the actual description of the microstructure, one can still deduce it as these theories do have physical representations of the involved elements (Jakobsen et al. 2000). The microstructural features of a composite medium control its elastic and electrical properties to a large extent, and as such, a consistent description of the seismic and electrical response of a medium should incorporate some detail of the microstructural configuration.

Pore-filling and grain-displacing are the most common gas hydrate morphologies observed in marine environments (e.g., Riedel et al. 2006, Collett et al. 2008; Boswell et al. 2009). At depth, under high-pressure and low-temperature conditions, it is feasible that hydrate forms as pore-filling within the pore space between sediment grains (Dai et al. 2012). A two-phase (hydrate and fluid) numerical model by Nimblett and Ruppel (2003) suggests that with increasing depth, hydrate forms more homogeneously in a pore-filling morphology than in fractures, which is consistent with our remotely-sensed $V_{P}$ and resistivity models of CNE03 (Fig. 2). Ivanov et al. (2007) analysis of core samples collected from the CNE03 pockmark indicate that hydrate forms in both pore-filling and grain-displacing morphologies, where hydrates can be distributed in grain-displacing morphology in various ways (e.g., Jakobsen et al., 2000, Ghosh et al., 2010; Best et al. 2013). Using elastic properties in a combined self-consistent approximation (SCA) and differential effective medium (DEM) model, Ghosh et al. (2010) demonstrated that a pore-filling morphology only moderately alters the inferred hydrate saturation in comparison to a mixture of pore-filling and grain-displacing morphology. Thus, although grain-displacing morphology may also be present at depth in CNE03, here, we applied the case of a pore-filling morphology for our SCA/DEM model to estimate the hydrate saturation within the deeper zone of the CNE03 pockmark.

The elastic and electrical properties of rocks and sediments are significantly affected by their microstructure. Therefore, the modelling should consider differences in the microstructural distribution of the rock constituents. In practice, collocated measurements of elastic and electrical properties are derived from a single microstructure; hence, capturing this consistency is essential for a rigorous rock physics approach. The SCA and DEM theories (and the combination of both) used in this study have elastic and electrical formulations with a consistent microstructural description between both properties. 
Sedimentary rocks generally contain phases that are biconnected (i.e., the pore space is connected, and the solid phase is also continuous) at any finite porosity (e.g., Berryman, 1992, Hornby et al., 1994). The model considered here is a biconnected sediment and pore space, where the pore space contains hydrate and brine connected phases. In effect, we have a three-phase composite consisting of connected sediments, hydrate, and brine. Limited observations available on hydrate morphology in sediments suggests that hydrate connectivity increases with the degree of hydrate saturation (e.g., Chaouachi et al. 2015). The use of a connected hydrate framework is appropriate for the CNE03 pockmark, because previous studies infer a moderate-to-high saturation (23-45\%) of hydrates at CNE03 (e.g., Westbrook et al., 2008b; Plaza-Faverola et al., 2010).

Sheng (1990) introduced an approach for creating a biconnected two-phase composite by combining the SCA and DEM theories. The DEM theory ensures the connectivity of the background phase (the starting phase), while the inclusions remain isolated at any given porosity (e.g., Berryman, 1992; Hornby et al., 1994). However, the SCA theory implies a biconnected effective microstructure between porosities of 0.4 and 0.6 (Sheng. 1990; Jakobsen et al., 2000). We refer to the porosities where the phases are connected in the SCA theory as the critical porosity $\left(\varphi_{c}\right)$ (e.g., Ellis 2008; Han et al. 2011a). This biconnectivity of phases might not be very important for modelling some properties, as it has been used successfully, for example, to model elastic properties (Sheng, 1990). Nevertheless, using the same approach for elastic DEM and electrical DEM of sandstone would grossly overestimate the electrical resistivity, well beyond what is seen in practice (e.g., Han et al., 2011a). Therefore, neither the SCA nor DEM theories can model independently the effective properties of a biconnected composite at any porosity, making a combination of both theories essential.

In this study, we have adopted the approach used by Han et al. (2011a). Although Han et al. (2011a) modelled sandstones, the approach is not specific to sandstones as the effective medium models are not specific to any composite, one of the reasons why these models are attractive (Sen et al. 1981; Milton, 1985, Berryman and Hoversten, 2013). Here, we used the effective medium models for clay-rich sediments (e.g., Hornby et al., 1994). The SCA and DEM equations used here (Appendix A) are isotropic formulations (e.g., Mavko et al., 1998, Ellis, 2008, Han et al. 2011a). For a two-phase (e.g., sediment and brine) medium (e.g., Sheng, 1990, Jakobsen et al., 2000, Han et al. 2011a), the procedure for creating a biconnected composite is as follows: First, we obtain an effective medium at the $\varphi_{c}$ (i.e., a porosity where the phases are biconnected, e.g., $0.4,0.5$, or 0.6 ) using the SCA theory; second, the DEM theory is used to obtain the effective medium at any porosity by starting with $\varphi_{c}$ value as the background; finally, sediments are added for porosities $<\varphi_{c}$, and brine for porosities $>\varphi_{c}$, as illustrated in Fig. 7 a. This gives the effective properties of a biconnected composite at any porosity. We model the hydrate-bearing sediments as a three-phase fully connected system that is composed of sediments, brine and hydrates. The mineral content of the sediments is known from the XRD analysis (section 4.4). We used the XRD information to construct a single mineral phase labeled as $C Q$ mix, a sediment composition that encompasses two primary minerals (clay, quartz) and three residual minerals (calcite, magnesium calcite, $\mathrm{K}$-feldspar). For modelling simplification, the three residual minerals were added to the quartz content. Thus, the $C Q$ mix contains $55 \%$ of clay and $45 \%$ of quartz minerals (Table 2 .

We obtain a three-phase effective medium by repeating the two-phase modelling ( $C Q \mathrm{mix}$ ), with the sequence determining the microstructural representation of the final medium (Han et al., 2011a). For a brine saturated, clay-rich sediment with pore-filling hydrates, where all the constituents are connected, the procedure is as follows: First, we use the two-phase SCA/DEM method to combine the hydrate and brine; then, we combine this hydrate+brine mix with the $C Q$ mix using the two-phase SCA/DEM approach again, giving the final three-phase effective medium (Fig. 77).

\subsection{Joint Elastic-Electrical SCA/DEM application to Seismic and CSEM Data from CNEO3}

We apply the effective medium modelling approach described above to estimate the hydrate content from the velocity and resistivity values as obtained from the seismic and CSEM datasets, respectively (section 3.1). The depth of interest ranged between 80-280 mbsf, where both velocity and resistivity anomalies are observed within CNE03 pipe-like structure are robust (Fig. 2), coincident with gas hydrate driven CSBZ. Ideally, one would calibrate the effective medium model from controlled laboratory experiments on hydrate-bearing sediments obtained from the site of interest. In the absence of such measurements, alternatively, we can use data from an undisturbed reference site, and thus, unbiased by free gas influx and hydrate formation/dissociation effects, or other local heterogeneities. Therefore, we have adopted the following approach: First, we fit a two-phase SCA/DEM model of sediments (CQ mix) and brine to the remotely-sensed data background response (no hydrate) by seeking a realistic combination of inputs. This step 
is done to calibrate some input model parameters in order to obtain a base model. Second, we apply the calibrated model parameters to obtain the three-phase effective medium modelling, as described in section 5.1

The inputs for individual constituents in effective medium models are (i) the bulk and shear moduli for the elastic models, (ii) the electrical resistivity for the electrical models, and (iii) the aspect ratios and volume fractions for both models. Although the bulk and shear moduli of clay minerals are poorly known because of the absence of large crystals for direct measurements, there is a reasonably narrow range that is widely used in the literature (e.g., Hornby et al., 1994; Jakobsen et al., 2000, Ellis, 2008, Han et al., 2011a). Likewise, electrical resistivity values of clay minerals are not well known, unlike quartz and carbonates which are usually taken as insulators. However, values that fall within the range of 1-100 $\Omega \mathrm{m}$ are reported (e.g., Telford et al., 1990; Han et al., 2011a). For the initial two-phase background model, we assumed a pore-fluid salinity range of 60-40 ppt ((Smith et al., 2014)) for background sediments between 80-280 mbsf, respectively. These salinity values are equivalent to resistivity range of $0.16-0.19 \Omega \mathrm{m}$, by applying the equations of state proposed by Fofonoff (1985); Lewis and Perkin (1981).

The values given in Table 3 were used to calibrate the two-phase SCA/DEM model to the averaged values of the background velocity $(1.7 \mathrm{~km} / \mathrm{s})$ and resistivity $(1.4 \Omega \mathrm{m})$, as shown in Figs $7 \mathrm{p}$, and 8 . These velocity and resistivity values were extracted from an area adjacent to the CNE03 pockmark (see section 3.1), and therefore, represent the $V_{P}$ and resistivity of the background sediments, as well as in good agreement with the values derived from the macro-scale background core measurements (section 4.1, Figs 2 and 3). Thus, the approach applied here maintains consistency between remotely-sensed data used for model calibration (background) and that from the anomaly (CNE03), supported by our core analysis. For an hydrate-free scenario, a porosity of $\sim 0.38$ (Fig. 8 ) is required to explain the anomalous $V_{P}$ and resistivity values observed within the CNE03 pipe-like structure, between $\sim 200-280$ mbsf (Fig. 2). Thus, a decrease in porosity due to an increase in the effective stress is insufficient to explain the observed $V_{P}$ and resistivity anomalies, because $\sim 0.38$ porosity is unrealistic for the Nyegga pockmark field, as documented by Hustoft et al. (2009).

We used a critical porosity $\varphi_{c}$ of 0.6 , which is consistent with the value commonly used for clay-rich sediments (e.g., Ellis 2008), and the average porosity measured in our sediment cores (Fig. 3p). Clay minerals have generally low aspect ratio (e.g., Hornby et al., 1994; Jakobsen et al., 2000). Although other minerals such as quartz might have higher aspect ratios, we used a single aspect ratio for simplicity to reduce the degrees of freedom of the model. This single aspect ratio acts as an effective (or average) aspect ratio, as suggested by Han et al. (2011a). We found that for an average porosity of 0.6 , a combination of 0.2 aspect ratio, $\varphi_{c}$ of 0.6 , and the physical properties of clay, quartz, and brine (Table 3), the two-phase model was able to fit the background sediment $V_{P}$ and CSEM resistivity averaged values of $1.7 \mathrm{~km} / \mathrm{s}$ and $1.4 \Omega \mathrm{m}$, respectively (Figs $8 \mathrm{a}$ and $\mathrm{b}$ ). The $V_{P}$ and resistivity data obtained from the background core analysis (Fig. 3 $\mathrm{b}$ ) also show good agreement with the calibrated model (Figs $8 \mathrm{a}$ and b), thus, validating our two-phase model calibration procedure.

Next, we used the parameters obtained from the model calibration to generate a three-phase model (where hydrates are included) by running the two-phase SCA/DEM step twice, as illustrated in Fig. 7p. Using the three-phase combined SCA/DEM method and hydrate properties taken from Goldberg et al. (2000); Best et al. (2013), we generated a three-phase model that describes the elastic and electrical response for the entire range of hydrate saturation (Fig. 9a). As a general trend, hydrate content increases with porosity, controlling the joint elastic-electrical properties of a pore-filling hydrate reservoir. At constant hydrate saturation, $V_{P}$ and electrical resistivity decrease with increasing porosity, as expected (i.e., for a given hydrate content the brine content increases with porosity, leading to decrease in bulk resistivity and sediment stiffness).

The generated three-phase model can be used as a template onto which the CSEM and seismic derived resistivities and velocities from points of interest can be co-rendered to estimate the hydrate content. We used velocities $V_{P 1}, V_{P 2}$, $V_{P 3}$ and constant resistivity $\sim 3 \Omega \mathrm{m}$ (Fig.22), to produce three sets of $V_{P}$-resistivity pairs in order to estimate the hydrate saturation within the three intervals shown in Fig. 2a. For each interval, the $V_{P}$ and resistivity are similar. Then, in the absence of in-situ porosity data, we can randomly assign porosity values between $0.55-0.65$ (in accordance with the fluctuating regional porosity (Hustoft et al. 2009), and the porosity derived from the CNE03 core measurement) to each $V_{P}$-resistivity pair in order to evaluate what hydrate saturation estimates correspond to these porosity ranges.

Fig. 9 shows the three sets of $V_{P}$-resistivity pairs co-rendered with our joint elastic-electrical SCA/DEM model for hydrate estimation at the porosities of interest. In the upper depth interval, we infer a hydrate saturation of $\sim 20-34 \%$. In the middle depth interval, the hydrate saturation locally increases up to $\sim 40 \%$ (Fig. 9p). In the deeper interval, the inferred hydrate saturation range is $\sim 30-48 \%$. For the entire porosity range $(0.55-0.65)$ and all depth intervals, the 
hydrate saturation varies between 20 and $48 \%$. Using the weighted contribution of each depth interval ( $V_{P}$ dependent) to this CSEM-seismic combined prediction of hydrate saturation, we infer that for porosities $0.55,0.6$ and 0.65 , the average of gas hydrate contents are $\sim 25,30$ and 40\%, respectively, within CNE03 between 80 and 280 mbsf. For the regional average porosity (0.6), the gas hydrate content is $\sim 23,33$ and $37 \%$ for depth intervals $80-180,180-200$ and 200-280 mbsf, respectively (Fig. 9 p).

\subsubsection{Sensitivity Analysis}

A sensitivity analysis was performed using CQ mixes that contain (a) $65 \%$ clay and $35 \%$ quartz, and (b) $45 \%$ clay and $55 \%$ quartz, thus, $\pm 10 \%$ clay content then the content obtained from the XRD analysis (section 4.4. Table 2). The analysis indicates subtle changes $(<2 \%)$ in gas hydrate saturation (Appendix B, Fig. A1), where lower clay content (higher quartz content) leads to a moderate decrease in gas hydrate content and vice versa. This is due to the higher values of the physical parameters (moduli, resistivity, density) of quartz in comparison to those of clay (Table 3 . However, there is no evidence to suggest the sediment composition is different from what we obtained from the XRD measurements performed on CNE03 core samples, which we used for the SCA/DEM modelling.

\section{Discussion}

A detailed characterisation of the study site lithology is essential to achieve a well constrained and accurate quantification of a gas hydrate deposit. Our results indicate that the background and CNE03 sediments exhibit significant differences in all the three scales (macro, meso, micro) analysed. Here, we highlight the distinctive lithology of the CNE03 pockmark and discuss the limitations and merits of the joint elastic-electrical SCA/DEM modelling scheme for gas hydrate quantification.

\subsection{CNE03 Lithology: Further Insights From Core Anlysis}

The background sediments demonstrate subtle variations in foraminiferal content and ice-rafted debris, with moderate to extensive bioturbation throughout. These sediments present consistent colour, with gradually increasing resistivity down-core, correlated with hemipelagic silts (Fig. 33). There is no evidence of deposition of mass wasting events, and stratification is only visible through horizons of intensely bioturbated material. Furthermore, this background core exhibits a continuous record of open marine sedimentation, unaffected by hydrothermal or chemosynthetic processes.

In contrast, the sediments obtained from the CNE03 pockmark show intact shell-rich horizons, cavities, and potent sulfide odour. This odour suggests anaerobic oxidation of methane as well as the presence of sulfide-oxidising bacteria that are hosted by the Isorropodon nyeggaensis sp. bivalves and consume methane as part of their metabolism (e.g., Distel, 1998). Thus, these features are all indicative of hydrate formation processes and dissociation upon core recovery. The properties of the CNE03 core are consistent with cores collected from pockmarks elsewhere in the North Atlantic (e.g., Paull et al., 2008; Panieri et al. 2014). The shell-rich horizons (Fig. 4. Table 1) detected in the CN2, and CN4 units of CNE03 (Fig. 3k) are interspersed with cavities across the core. Radiocarbon analysis to compare these shells and benthic foraminifera to those obtained from the Storegga Slide (e.g., Evans et al., 1996, Hjelstuen et al. 2005; Micallef et al., 2007), may elucidate whether a widespread methane release in Nyegga and the Storegga Slide occurred simultaneously or sequentially.

Fragments of carbonate nodules were observed in the vicinity of these shell-rich horizons, consistent with the recovery of methane-derived authigenic carbonates from nearby pockmarks (Hovland et al., 2005; Mazzini et al. 2006; Ivanov et al. 2010). Authigenic carbonates normally precipitate in the near-seafloor sediments as a result of methane oxidation by microbial communities (e.g., Hustoft et al., 2007, Mazzini et al., 2006; Petersen et al., 2010, Riboulot et al., 2016; Crémière et al. 2016). Therefore, we postulate that authigenic carbonates may contribute to the higher resistivity observed near the seafloor $(<10 \mathrm{mbsf})$ at CNE03, whereas the resistivity and $V_{P}$ anomalies detected at depth are most likely due to the presence of hydrate rather than authigenic carbonate. However, our core data does not extend deep enough to confirm that. We hypothesise that both the shell-rich horizons and authigenic carbonates were formed during periodic venting of methane from this pockmark, consistent with previous findings from the Nyegga pockmark field (Paull et al., 2008; Vaular et al. 2010). 
Overall, we observe very little difference between the elastic and electrical properties of the background samples and the CNE03 samples (Fig. 3p). Due to the meso-scale measurements confining pressure and the nature of contact between the electrodes and samples (section 3.2.2), the $V_{P}$ and resistivity values are overestimated in comparison to the macro-scale measurements, thus limiting their ability to provide evidence of hydrate dissociation in the CNE03 core. However, we postulate that unpressurized recovery of this core has led to hydrate dissociation (Fig. 1); and consequently, the release of gas via porous flow due to the high porosity of the sediment $(\sim 0.6)$, leaving mainly water-filled regions within the CNE03 cores (Fig. 3).

\subsection{SCA/DEM Modelling for Hydrates}

In addition to being sensitive to microstructural details, rock physics models are also sensitive to the petrophysical properties of the sediments, making them prone to non-uniqueness. The joint elastic-electrical approach contributes in mitigating this non-uniqueness. To constrain further the rock physics models, we made use of data from a comprehensive analysis of the retrieved sediment cores. The information from core data assists in constraining important controls on elastic and electrical properties such as the mineralogy and porosity. These steps helped to reduce the non-uniqueness in the models significantly.

The aspect ratio used in the modelling is not very well-constrained, as it is difficult to estimate accurate aspect ratios, even from core data, due to the variety of aspect ratios that can be found in sediments. Clay minerals have low aspect ratios while minerals such as quartz and calcite are normally assigned with aspect ratios equal to unity (e.g., Hornby et al., 1994; Mavko et al., 1998; Jakobsen et al. 2000). Han et al. (2011a) suggested calculating an effective aspect ratio of each inclusion by averaging individual aspect ratios weighted by their volume fractions as a way of mitigating this complexity. Although we arrived at the aspect ratio of 0.2 by fitting a two-phase model to the background response, this value is in agreement with that derived from the averaging approach suggested by Han et al. (2011a). If we assume the pore space (brine) is of the same low aspect ratio as clay, and both of them equal to $1 / 40$ (e.g., Jakobsen et al., 2000), then assigning an aspect ratio of 1 to quartz and averaging the aspect ratios by their volume fractions gives an aspect ratio of about 0.2 .

Clay-rich sediments are anisotropic when the clay minerals are preferentially aligned in a given direction. However, we have used isotropic formulations of the effective medium theories because a comparison between CSEM isotropic and anisotropic inversions suggested that anisotropy at CEN03 is very subtle, and the isotropic models were able to fit the data adequately (Attias et al. 2016). Therefore, accounting for anisotropy without the information/data to constrain it would lead to more uncertainties from additional free parameters (e.g., anisotropic mineral moduli, orientation distribution functions). Consequently, we applied an isotropic approach, where the low aspect ratio clay minerals are randomly aligned.

\subsection{Modelling Limitations}

The main limitation of our SCA/DEM joint elastic-electrical modelling approach is that it assumes a pore-filling morphology. We chose to use a pore-filling morphology partly based on the evidence mentioned above (sections 1 . and 5.1 , and partly due to modelling considerations. The modelling considerations result from model parameterization, aiming to minimize the number of free (unconstrained) parameters as much as possible to reduce uncertainties. The trade-off is between accounting ideally for the geologic complexity via formulating a joint modelling approach, and a more simplistic approach that only accounts for some of the geological complexity yet remains predictive. The pore-filling morphology provides a balance between subsurface geological complexity and model reliability.

Another limitation is related to the difference in resolutions of the seismic velocity and CSEM remote sensing data that we used in our SCA/DEM modelling scheme. Attias et al. (2018) imaged the resistivity structure of the CNE03 pockmark in high-resolution using 2.5-D CSEM inversions of a towed-receiver data individually and jointly with seafloor receivers data. Their results were supported by a linearized sensitivity analysis to the inversion models by evaluating the model Jacobian matrix J (e.g., Farquharson and Oldenburg, 1996; Key, 2016). By co-rendering the inversion models with the $\mathbf{J}$ contours, Attias et al. (2018) demonstrated the high-sensitivity of the model to the entire pipe-structure at CNE03. (Plaza-Faverola et al. 2010) seismic reflection sections and velocity model of the CNE03 pipe-structure agrees well with our CSEM inversion models, which increase the level of our confidence in the joint electrical and elastic properties. Using the best fitting model, we explored the possible physical properties (porosity and saturation) via the joint elastic-electrical modelling approach. 
The joint elastic-electrical effective medium modelling scheme presented here provides a rigorous method to quantify the saturation of gas hydrate in a pore-filling morphology, as it considers microstructural information. Although this modelling approach might not be ideal for the CNE03 pockmark, the concepts and workflow described above can be applied to quantify gas hydrate reservoirs in a purely pore-filling morphology with fine-grained muddy clay sediment, as documented in studies from South China Sea (e.g., Zhang et al., 2007; Zhong et al., 2017) and eastern Nankai Trough, Japan (Yoneda et al. 2017).

\subsection{CNE03: Gas Hydrate Quantification}

Previous seismic velocity (using reflection time tomography) and CSEM resistivity (using Archie's) analysis to predict the hydrate content within CNE03 inferred saturations of 14-27\% of total volume, which is equal to 23$45 \%$ of pore volume (Plaza-Faverola et al. 2010), and $\sim 38 \%$ of pore volume (Attias et al., 2016), respectively. Here, our joint elastic-electrical SCA/DEM approach yields an inferred hydrate saturation of $\sim 23,33$ and $37 \%$ for the three (depth dependent) $V_{P}$ intervals, as described in section 5.2 Thus, comparable with both the seismic and CSEM individual predictions, but provides a more depth discretized assessment of hydrate saturation via rigorous rock physics framework; though ultimately limited by our assumption of a pore-filling morphology.

Comparisons of coincident electrical and elastic datasets with the joint elastic-electrical SCA/DEM models enabled us to determine the depth-dependent lower and upper bounds of the gas hydrate saturation in the CNE03 pipelike structure (Fig. 9). The $V_{P}$ and resistivity anomalies observed within the CNE03 pipe-like structure above the BGHSZ implied to be due to localised hydrates rather than porosity decrease (effective stress increase) with depth. Otherwise, a porosity of $\sim 0.38$ would be required to account for these anomalies (Fig. 8), which is unrealistic for the Nyegga pockmark field (section 5.2). Additionally, if that were solely a porosity/stress effect, these anomalies should have been laterally uniform, and not only constrained to the spatial boundaries of the CNE03 pipe-like structure, as evident from both datasets (Fig. 2).

The CNE03 pipe-like structure is fed by free gas from beneath the BGSHZ (Bünz et al., 2003, Plaza-Faverola et al., 2010; Attias et al. 2016), it is plausible that both gas hydrate and free gas coexist within this pipe-like structure, as inferred for similar pipe-like structures offshore Svalbard (Goswami et al., 2015, 2016). However, seismic tomography models indicate a high $V_{P}$ in the immediate region above the BGHSZ, which is interpreted as hydrates (Plaza-Faverola et al. 2010), coincident with high resistivity anomaly (Attias et al., 2016). Beneath the BGHSZ, the $V_{P}$ decrease significantly due to the presence of a free gas layer (Plaza-Faverola et al., 2010). This high-to-low trend in $V_{P}$ across the BGHSZ of CNE03 indicates that when free gas propagates into the gas hydrate stability zone (GHSZ), the bulk amount of it forms hydrates. Alternatively, if substantial volumes would remain in a free gas state within the GHSZ, the $V_{P}$ in this region should present lower values than those documented by Plaza-Faverola et al. (2010). Therefore, we infer that the amount of free gas within the GHSZ of CNE03 is insignificant. Consequently, we chose to neglect the free gas from our modelling of gas hydrate saturation (section 5.2), thus avoid introducing unknown parameters that may increase the model uncertainties and most likely bias the results.

\section{Summary and Conclusions}

This paper offers both qualitative and quantitative analysis of the CNE03 gas hydrate pipe-like structure, in the Nyegga region, Offshore Norway. Sediment cores were characterised at macro-, meso- and micro- scale for lithological and petrophysical properties, providing important constraints on model inputs. A rock physics framework that links the elastic and electrical properties of an effective medium was applied to quantify gas hydrate saturation from coincident marine CSEM and seismic data. The self-consistent approximation and differential effective medium theories were combined to generate a fully connected three-phase model, with the steps chosen to achieve an idealised representation of pore-filling hydrate morphology.

Based on this work, we conclude the following:

1. The sediment core analysis provides evidence for the formation and dissociation of gas hydrate within the CNE03 pipe-like structure, as inferred from the recovery of hydrate and chemosynthetic bivalves. 
2. The background $V_{P}$ and resistivity values obtained from the macro-scale measurements are comparable with the seismic velocity and CSEM resistivity remote sensing data derived from the area adjacent to the CNE03 pockmark. However, the macro-scale measurements were derived from 6-8 m sediment cores; and therefore, may not ideally represent the remotely-sensed seismic velocity and CSEM resistivity obtained from the deeper layers of the area adjacent to the CNE03 pockmark.

3. Comparison of the collocated CSEM and seismic datasets with the joint elastic-electrical SCA/DEM model indicate that the gas hydrate saturation within CNE03 ranges from $\sim 20 \%$ to $\sim 48 \%$, at a porosity range of $0.55-$ 0.65 , between depths of 80 and 280 mbsf.

4. For porosities $0.55,0.6$, and 0.65 , the hydrate saturation varies between $\sim 20-34 \%, \sim 23-37 \%$, and $\sim 30-48 \%$, whereas the weighted means are $\sim 25,30$ and $40 \%$, respectively.

5. The hydrate saturation at $\mathrm{CNE} 03$ gradually increases with depth, whereas the highest hydrate saturation is near the base of the gas hydrate stability zone.

6. Our elastic-electrical combined analysis predicts hydrate saturation of $\sim 23-37 \%$, consistent with the elastic (23-45\%) and electrical ( 38\%) individual predictions, previously conducted at CNE03.

7. The coupling of seismic and CSEM data using a joint elastic-electrical effective medium model is a more rigorous framework for the estimation of hydrate saturation, particularly when model parameters are wellconstrained.

\section{Acknowledgments}

This paper forms part of the PhD studies of Eric Attias, funded by Rock Solid Images Ltd., the University of Southampton, and the National Oceanography Centre Southampton (NOCS). A Wolfson Research Merit Award supported TAM. The authors are grateful to Peter Telling for the acquisition of the cores used in this study, as part of the UK Natural Environment Research Council (NERC) Arctic Research Programme (project: landslide-tsunami risk to the UK; NERC Grant NE/K00008X/1). We also thank the British Ocean Sediment Core Research Facility at NOCS, and the curators S. MacLachan and M. Edwards for their services in maintaining the sediment cores and aiding with the analytical techniques. Additionally, we thank Tongcheng Han and Héctor Marín-Moreno for productive discussions. We thank the captain, crew and scientific party of R/V Pelagia. The data used in this paper are available via https://doi.pangaea.de/10.1594/PANGAEA.876610.

\section{References}

Attias, E., Weitemeyer, K., Hölz, S., Naif, S., Minshull, T.A., Best, A.I., Haroon, A., Jegen-Kulcsar, M., Berndt, C., 2018. High-resolution resistivity imaging of marine gas hydrate structures by combined inversion of CSEM towed and ocean-bottom receiver data. Geophys. J. Int. 214, 1701-1714.

Attias, E., Weitemeyer, K., Minshull, T.A., Best, A.I., Sinha, M., Jegen-Kulcsar, M., Hölz, S., Berndt, C., 2016. Controlled-source electromagnetic and seismic delineation of subseafloor fluid flow structures in a gas hydrate province, offshore Norway. Geophys. J. Int. 206, 1093-1110.

Berndt, C., Bünz, S., Mienert, J., 2003. Polygonal fault systems on the mid-Norwegian margin: a long-term source for fluid flow. Geological Society, London, Special Publications 216, 283-290.

Berryman, J.G., 1992. Single-scattering approximations for coefficients in Biots equations of poroelasticity. The Journal of the Acoustical Society of America 91, 551-571

Berryman, J.G., Hoversten, G.M., 2013. Modelling electrical conductivity for earth media with macroscopic fluid-filled fractures. Geophys. Prospect. 61, 471-493.

Best, A.I., 1992. The prediction of the reservoir properties of sedimentary rocks from seismic measurements. Ph.D. thesis. University of Reading. Best, A.I., Priest, J.A., Clayton, C.R., Rees, E.V., 2013. The effect of methane hydrate morphology and water saturation on seismic wave attenuation in sand under shallow sub-seafloor conditions. Earth Planet. Sci. Lett. 368, 78-87.

Bin, B., Rukai, Z., Songtao, W., Wenjing, Y., Gelb, J., Gu, A., Zhang, X., Ling, S., 2013. Multi-scale method of Nano (Micro)-CT study on microscopic pore structure of tight sandstone of Yanchang Formation, Ordos Basin. Petroleum Exploration and Development 40, $354-358$.

Boswell, R., Shelander, D., Lee, M., Latham, T., Collett, T., Guerin, G., Moridis, G., Reagan, M., Goldberg, D., 2009. Occurrence of gas hydrate in Oligocene Frio sand: Alaminos Canyon Block 818: Northern Gulf of Mexico. Mar. Petrol. Geol. 26, 1499-1512.

Boswell, R., Shipp, C., Reichel, T., Shelander, D., Saeki, T., Frye, M., Shedd, W., Collett, T.S., McConnell, D.R., 2015. Prospecting for marine gas hydrate resources. Interpretation 4, SA13-SA24. 
Boswell, R., Yamamoto, K., Lee, S.R., Collett, T., Kumar, P., Dallimore, S., 2014. Chapter 8 - methane hydrates, in: Letcher, T.M. (Ed.), Future Energy 2nd ed.. Elsevier, pp. 159-178.

Bouriak, S., Vanneste, M., Saoutkine, A., 2000. Inferred gas hydrates and clay diapirs near the Storegga Slide on the southern edge of the Vøring Plateau, offshore Norway. Mar. Geol. 163, 125-148.

Brekke, H., 2000. The tectonic evolution of the Norwegian Sea Continental Margin with emphasis on the Vøring and Møre Basins. Dynamics of the Norwegian Margin 167, 327-378.

Bünz, S., Mienert, J., Berndt, C., 2003. Geological controls on the Storegga gas-hydrate system of the mid-Norwegian continental margin. Earth Planet. Sci. Lett. 209, 291-307.

Carcione, J.M., Ursin, B., Nordskag, J.I., 2007. Cross-property relations between electrical conductivity and the seismic velocity of rocks. Geophysics 72, E193-E204.

Carrara, E., Pece, R., Roberti, N., 1994. Geoelectrical and seismic prospections in hydrogeology: model and master curves for the evaluation of porosity and water saturation. Pure Appl. Geophys. 143, 729-751.

Cavanaugh, C.M., 1983. Symbiotic chemoautotrophic bacteria in marine invertebrates from sulphide-rich habitats. Nature 302, 58-61.

Chand, S., Minshull, T.A., Priest, J.A., Best, A.I., Clayton, C.R., Waite, W.F., 2006. An effective medium inversion algorithm for gas hydrate quantification and its application to laboratory and borehole measurements of gas hydrate-bearing sediments. Geophys. J. Int. 166, $543-552$.

Chaouachi, M., Falenty, A., Sell, K., Enzmann, F., Kersten, M., Haberthür, D., Kuhs, W.F., 2015. Microstructural evolution of gas hydrates in sedimentary matrices observed with synchrotron X-ray computed tomographic microscopy. Geochem. Geophys. Geosyst. 16, 1711-1722.

Chipera, S.J., Bish, D.L., 2002. FULLPAT: a full-pattern quantitative analysis program for X-ray powder diffraction using measured and calculated patterns. J. Appl. Crystallogr. 35, 744-749.

Cleary, M.P., Lee, S.M., Chen, I.W., 1980. Self-consistent techniques for heterogeneous media. J. Eng. Mech. Div. 106, 861-887.

Collett, T., Riedel, M., Cochran, J., Boswell, R., Presley, J., Kumar, P., Sathe, A., Sethi, A., Lall, M., Sibal, V., 2008. the NGHP Expedition 01 Scientists. Indian National Gas Hydrate Program Expedition 01 Initial Reports. Directorate General of Hydrocarbons, Noida 1, 2.

Collett, T.S., 2002. Energy resource potential of natural gas hydrates. AAPG bulletin 86, 1971-1992.

Collett, T.S., Boswell, R., 2012. Resource and hazard implications of gas hydrates in the northern gulf of mexico: Results of the 2009 joint industry project leg $\{\mathrm{II}\}$ drilling expedition. Mar. Petrol. Geol. 34, 1-3.

Collett, T.S., Johnson, A.H., Knapp, C.C., Boswell, R., 2009. Natural gas hydrates: a review. AAPG memoir 89, $146-220$.

Collett, T.S., Ladd, J., 2000. Detection of gas hydrate with downhole logs and assessment of gas hydrate concentrations (saturations) and gas volumes on the Blake Ridge with electrical resistivity log data, in: Proceedings of the Ocean Drilling Program. Scientific Results, pp. $179-191$.

Collett, T.S., et al., 1998. Well log evaluation of gas hydrate saturations, in: SPWLA 39th Annual Logging Symposium, Society of Petrophysicists and Well-Log Analysts. pp. 1-14.

Crémière, A., Lepland, A., Chand, S., Sahy, D., Kirsimäe, K., Bau, M., Whitehouse, M.J., Noble, S.R., Martma, T., Thorsnes, T., et al., 2016. Fluid source and methane-related diagenetic processes recorded in cold seep carbonates from the Alvheim channel, central North Sea. Chem. Geol. 432, 16-33.

Dahlgren, K., Vorren, T.O., Laberg, J.S., 2002. Late Quaternary glacial development of the mid-Norwegian margin: 65 to $68^{\circ}$ N. Mar. Petrol. Geol. 19, 1089-1113.

Dai, S., Santamarina, J.C., Waite, W.F., Kneafsey, T.J., 2012. Hydrate morphology: Physical properties of sands with patchy hydrate saturation. J. Geophys. Res. 117. doi 10.1029/2012JB009667

Dalland, A., Worsley, D., Ofstad, K., 1988. A Lithostratigraphic Scheme for the Mesozoic and Cenozoic and Succession Offshore Mid-and Northern Norway. Norwegian Petroleum Directorate Bulletin 4.

Delbos, F., Gilbert, J.C., Glowinski, R., Sinoquet, D., 2006. Constrained optimization in seismic reflection tomography: a Gauss-Newton augmented Lagrangian approach. Geophys. J. Int. 164, 670-684.

Delbos, F., Sinoquet, D., Gilbert, J.C., Masson, R., 2001. Trust-region Gauss-Newton method for reflection tomography. KIM 2001 Annual Report, Institut Français du Pétrole, Rueil, France

Distel, D.L., 1998. Evolution of chemoautotrophic endosymbioses in bivalves. Bioscience 48, 277-286.

Du, Z., MacGregor, L.M., 2010. Reservoir characterization from joint inversion of marine CSEM and seismic AVA data using Genetic Algorithms: a case study based on the Luva gas field. pp. 737-741.

Eberl, D., 2003. User guide to RockJock-A program for determining quantitative mineralogy from X-ray diffraction data, in: US Geological Survey, p. 47.

Eidvin, T., Brekke, H., Riis, F., Renshaw, D.K., 1998. Cenozoic stratigraphy of the Norwegian Sea continental shelf, 64N-68N. Norsk Geologisk Tidsskrift 78, 125-152.

Ellis, M.H., 2008. Joint seismic and electrical measurements of gas hydrates in continental margin sediments. Ph.D. thesis. University of Southampton.

Ellis, M.H., Sinha, M.C., Minshull, T.A., Sothcott, J., Best, A.I., 2010. An anisotropic model for the electrical resistivity of two-phase geologic materials. Geophysics 75, E161-E170.

Evans, D., King, E., Kenyon, N., Brett, C., Wallis, D., 1996. Evidence for long-term instability in the Storegga Slide region off western Norway. Mar. Geol. 130, 281-292.

Farquharson, C., Oldenburg, D., 1996. Approximate sensitivities for the electromagnetic inverse problem. Geophys. J. Int. 126, 235-252.

Fofonoff, N., 1985. Physical properties of seawater: A new salinity scale and equation of state for seawater. J. Geophys. Res. 90, 3332-3342.

Ghosh, R., Sain, K., Ojha, M., 2010. Effective medium modeling of gas hydrate-filled fractures using the sonic log in the Krishna-Godavari basin, offshore eastern India. J. Geophys. Res. 115.

Goldberg, D.S., Collett, T.S., Hyndman, R.D., 2000. Ground truth: in-situ properties of hydrate, in: Natural Gas Hydrate. Springer, pp. 295-310.

Goswami, B.K., Weitemeyer, K.A., Bünz, S., Minshull, T.A., Westbrook, G.K., Ker, S., Sinha, M.C., 2017. Variations in pockmark composition at the Vestnesa Ridge: Insights from marine controlled source electromagnetic and seismic data. Geochem. Geophys. Geosyst. 18, $1111-1125$.

Goswami, B.K., Weitemeyer, K.A., Minshull, T.A., Sinha, M.C., Westbrook, G.K., Chabert, A., Henstock, T.J., Ker, S., 2015. A joint electromagnetic and seismic study of an active pockmark within the hydrate stability field at the Vestnesa Ridge, West Svalbard margin. J. Geophys. Res. 
$120,6797-6822$.

Goswami, B.K., Weitemeyer, K.A., Minshull, T.A., Sinha, M.C., Westbrook, G.K., Marín-Moreno, H., 2016. Resistivity image beneath an area of active methane seeps in the west Svalbard continental slope. Geophys. J. Int. 207, 1286-1302.

Han, T., Best, A.I., MacGregor, L.M., Sothcott, J., Minshull, T.A., 2011a. Joint elastic-electrical effective medium models of reservoir sandstones. Geophys. Prospect. 59, 777-786.

Han, T., Best, A.I., Sothcott, J., MacGregor, L.M., 2011b. Joint elastic-electrical properties of reservoir sandstones and their relationships with petrophysical parameters. Geophys. Prospect. 59, 518-535.

Han, T., Clennell, M.B., Cheng, A.C., Pervukhina, M., 2016. Are self-consistent models capable of jointly modeling elastic velocity and electrical conductivity of reservoir sandstones? Geophysics 81, D377-D382.

Hill, R., 1965. A self-consistent mechanics of composite materials. J. Mech. Phys. Solids 13, $213-222$.

Hjelstuen, B.O., Sejrup, H.P., Haflidason, H., Nygrd, A., Ceramicola, S., Bryn, P., 2005. Late Cenozoic glacial history and evolution of the Storegga Slide area and adjacent slide flank regions, Norwegian continental margin. Mar. Petrol. Geol. 22, 57-69.

Holland, M., Schultheiss, P., Roberts, J., Druce, M., 2008. Observed gas hydrate morphologies in marine sediments, in: paper 5691 presented at the 6th International Conference on Gas Hydrates, Chevron, Vancouver, B. C., Canada, 6-10 July.

Hornby, B.E., Schwartz, L.M., Hudson, J.A., 1994. Anisotropic effective-medium modeling of the elastic properties of shales. Geophysics 59, $1570-1583$

Hovland, M., Svensen, H., 2006. Submarine pingoes: Indicators of shallow gas hydrates in a pockmark at Nyegga, Norwegian Sea. Mar. Geol. $228,15-23$

Hovland, M., Svensen, H., Forsberg, C.F., Johansen, H., Fichler, C., Foss, J.H., et al., 2005. Complex pockmarks with carbonate-ridges off mid-Norway: products of sediment degassing. Mar. Geol. 218, 191-206.

Hustoft, S., Dugan, B., Mienert, J., 2009. Effects of rapid sedimentation on developing the Nyegga pockmark field: Constraints from hydrological modeling and 3-D seismic data, offshore mid-Norway. Geochem. Geophys. Geosyst. 10, doi: 10.1029/2009GC002409.

Hustoft, S., Mienert, J., Bünz, S., Nouzé, H., 2007. High-resolution 3D-seismic data indicate focussed fluid migration pathways above polygonal fault systems of the mid-Norwegian margin. Mar. Geol. 245, 89-106.

Hyndman, R., Yuan, T., Moran, K., 1999. The concentration of deep sea gas hydrates from downhole electrical resistivity logs and laboratory data. Earth Planet. Sci. Lett. 172, 167-177.

Ivanov, M., Blinova, V., Kozlova, E., Westbrook, G.K., Mazzini, A., Minshull, T., Nouzé, H., 2007. First sampling of gas hydrate from the Vøring Plateau. Eos, Transactions American Geophysical Union 88, 209-212.

Ivanov, M., Mazzini, A., Blinova, V., Kozlova, E., Laberg, J.S., Matveeva, T., Taviani, M., Kaskov, N., 2010. Seep mounds on the southern Vøring plateau (offshore norway). Mar. Petrol. Geol. 27, 1235-1261.

Jakobsen, M., Hudson, J.A., Minshull, T.A., Singh, S.C., 2000. Elastic properties of hydrate-bearing sediments using effective medium theory. J. Geophys. Res. 105, 561-577.

Judd, A., Hovland, M., 1992. The evidence of shallow gas in marine sediments. Cont. Shelf Res. 12, 1081-1095.

Karstens, J., Haflidason, H., Becker, L.W.M., Berndt, C., Rüpke, L., Planke, S., Liebetrau, V., Schmidt, M., Mienert, J., 2018. Glacigenic sedimentation pulses triggered post-glacial gas hydrate dissociation. Nature Communications 9, 635.

Key, K., 2016. MARE2DEM: a 2-D inversion code for controlled-source electromagnetic and magnetotelluric data. Geophys. J. Int. $207,571-588$.

Kjeldstad, A., Skogseid, J., Langtangen, H., Bjørlykke, K., Høeg, K., 2003. Differential loading by prograding sedimentary wedges on continental margins: An arch-forming mechanism. J. Geophys. Res. 108, doi:10.1029/2001JB001145.

Klauda, J.B., Sandler, S.I., 2005. Global distribution of methane hydrate in ocean sediment. Energy \& Fuels 19, 459-470.

Krylova, E., Gebruk, A., Portnova, D., Todt, C., Haflidason, H., 2011. New species of the genus Isorropodon (Bivalvia: Vesicomyidae: Pliocardiinae) from cold methane seeps at Nyegga (Norwegian Sea, Vøring Plateau, Storrega Slide). Journal of the Marine Biological Association of the United Kingdom 91, 1135-1144.

Lee, J.H., Baek, Y.S., Ryu, B.J., Riedel, M., Hyndman, R.D., 2005. A seismic survey to detect natural gas hydrate in the East Sea of Korea. Mar. Geophys. Res. 26, 51-59.

Lewis, E., Perkin, R., 1981. The Practical Salinity Scale 1978: conversion of existing data. Deep Sea Res. 28, 307-328.

Li, A., Davies, R.J., Yang, J., 2016. Gas trapped below hydrate as a primer for submarine slope failures. Mar. Geol. 380, $264-271$.

Lodolo, E., Camerlenghi, A., Madrussani, G., Tinivella, U., Rossi, G., 2002. Assessment of gas hydrate and free gas distribution on the South Shetland margin (Antarctica) based on multichannel seismic reflection data. Geophys. J. Int. 148, 103-119.

Malinverno, A., Kastner, M., Torres, M., Wortmann, U., 2008. Gas hydrate occurrence from pore water chlorinity and downhole logs in a transect across the northern Cascadia margin (Integrated Ocean Drilling Program Expedition 311). J. Geophys. Res. 113.

Marín-Moreno, H., Minshull, T.A., Westbrook, G.K., Sinha, B., 2015. Estimates of future warming-induced methane emissions from hydrate offshore west Svalbard for a range of climate models. Geochem. Geophys. Geosyst. 16, 1307-1323.

Mavko, G., Mukerji, T., Dvorkin, J., 1998. The rock physics handbook: Tool for seismic analysis in porous media. Cambridge University Press.

Mazzini, A., Svensen, H., Hovland, M., Planke, S., 2006. Comparison and implications from strikingly different authigenic carbonates in a Nyegga complex pockmark, G11, Norwegian Sea. Mar. Geol. 231, 89-102.

McCann, C., Sothcott, J., 1992. Laboratory measurements of the seismic properties of sedimentary rocks. Geological Society, London, Special Publications 65, 285-297.

Micallef, A., Masson, D.G., Berndt, C., Stow, D.A., 2007. Morphology and mechanics of submarine spreading: A case study from the Storegga Slide. J. Geophys. Res. 112.

Milkov, A.V., 2004. Global estimates of hydrate-bound gas in marine sediments: how much is really out there? Earth Science Reviews 66, 183-197.

Milkov, A.V., Dickens, G.R., Claypool, G.E., Lee, Y.J., Borowski, W.S., Torres, M.E., Xu, W., Tomaru, H., Tréhu, A.M., Schultheiss, P., 2004. Co-existence of gas hydrate, free gas, and brine within the regional gas hydrate stability zone at Hydrate Ridge (Oregon margin): evidence from prolonged degassing of a pressurized core. Earth Planet. Sci. Lett. 222, 829-843.

Milkov, A.V., Sassen, R., 2002. Economic geology of offshore gas hydrate accumulations and provinces. Mar. Petrol. Geol. $19,1-11$. 
Milton, G., 1985. The coherent potential approximation is a realizable effective medium scheme. Communications in Mathematical Physics 99, 463-500.

Nimblett, J., Ruppel, C., 2003. Permeability evolution during the formation of gas hydrates in marine sediments. J. Geophys. Res. 108.

North, L., Best, A.I., Sothcott, J., MacGregor, L., 2013. Laboratory determination of the full electrical resistivity tensor of heterogeneous carbonate rocks at elevated pressures. Geophys. Prospect. 61, 458-470.

North, L.J., Best, A.I., 2014. Anomalous electrical resistivity anisotropy in clean reservoir sandstones. Geophys. Prospect. 62, $1315-1326$.

Panieri, G., James, R.H., Camerlenghi, A., Westbrook, G.K., Consolaro, C., Cacho, I., Cesari, V., Cervera, C.S., 2014. Record of methane emissions from the West Svalbard continental margin during the last 23.500 yrs revealed by $\delta^{13} \mathrm{C}$ of benthic foraminifera. Global and Planetary Change $122,151-160$

Paull, C.K., Ussler, W., Holbrook, W.S., Hill, T.M., Keaten, R., Mienert, J., Haflidason, H., Johnson, J.E., Winters, W.J., Lorenson, T.D., 2008. Origin of pockmarks and chimney structures on the flanks of the Storegga Slide, offshore Norway. Geo-Mar. Lett. 28, 43-51.

Pearson, C., Halleck, P., McGuire, P., Hermes, R., Mathews, M., 1983. Natural gas hydrate deposits: A review of in situ properties. The Journal of Physical Chemistry 87, 4180-4185.

Petersen, C.J., Bünz, S., Hustoft, S., Mienert, J., Klaeschen, D., 2010. High-resolution P-Cable 3D seismic imaging of gas chimney structures in gas hydrated sediments of an Arctic sediment drift. Mar. Petrol. Geol. 27, 1981-1994.

Pinero, E., Marquardt, M., Hensen, C., Haeckel, M., Wallmann, K., 2013. Estimation of the global inventory of methane hydrates in marine sediments using transfer functions. Biogeosciences 10, 959-975.

Plaza-Faverola, A., Bünz, S., Mienert, J., 2011. Repeated fluid expulsion through sub-seabed chimneys offshore Norway in response to glacial cycles. Earth Planet. Sci. Lett. 305, 297-308.

Plaza-Faverola, A., Bünz, S., Mienert, J., 2012. The free gas zone beneath gas hydrate bearing sediments and its link to fluid flow: 3-D seismic imaging offshore mid-Norway. Mar. Geol. 291-294, 211-226.

Plaza-Faverola, A., Westbrook, G.K., Ker, S., Exley, R.J., Gailler, A., Minshull, T.A., Broto, K., 2010. Evidence from three-dimensional seismic tomography for a substantial accumulation of gas hydrate in a fluid-escape chimney in the Nyegga pockmark field, offshore Norway. J. Geophys. Res. 115, doi: 10.1029/2009JB007078.

Riboulot, V., Cattaneo, A., Lanfumey, V., Voisset, M., Cauquil, E., et al., 2011. Morphological signature of fluid flow seepage in the Eastern Niger Submarine Delta (ENSD), in: Offshore Technology Conference, Houston, TX, USA. OTC 21744.

Riboulot, V., Sultan, N., Imbert, P., Ker, S., 2016. Initiation of gas-hydrate pockmark in deep-water Nigeria: Geo-mechanical analysis and modelling. Earth Planet. Sci. Lett. 434, 252-263.

Riedel, M., Collett, T., Malone, M., 2009. Gas hydrate drilling transect across northern Cascadia margin-IODP Expedition 311. Geological Society, London, Special Publications 319, 11-19.

Riedel, M., Novosel, I., Spence, G.D., Hyndman, R.D., Chapman, R.N., Solem, R.C., Lewis, T., 2006. Geophysical and geochemical signatures associated with gas hydrate-related venting in the northern Cascadia margin. Geological Society of America Bulletin 118, 23-38.

Riedel, M., Spence, G., Chapman, N., Hyndman, R., 2002. Seismic investigations of a vent field associated with gas hydrates, offshore Vancouver Island. J. Geophys. Res. 107, doi: 10.1029/2001JB000269.

Ruppel, C., 2011. Methane hydrates and contemporary climate change. Nature Education Knowledge 3, 29.

Schwalenberg, K., Haeckel, M., Poort, J., Jegen, M., 2010. Evaluation of gas hydrate deposits in an active seep area using marine controlled source electromagnetics: Results from Opouawe bank, Hikurangi Margin, New Zealand. Mar. Geol. 272, 79-88.

Schwalenberg, K., Rippe, D., Koch, S., Scholl, C., 2017. Marine-controlled source electromagnetic study of methane seeps and gas hydrates at Opouawe Bank, Hikurangi Margin, New Zealand. J. Geophys. Res. 122, 3334-3350.

Sen, P., Scala, C., Cohen, M., 1981. A self-similar model for sedimentary rocks with application to the dielectric constant of fused glass beads. Geophysics 46, 781-795.

Senger, K., Bünz, S., Mienert, J., 2010. First-Order Estimation of in-Place Gas Resources at the Nyegga Gas Hydrate Prospect, Norwegian Sea. Energies 3, 2001-2026.

Sheng, P., 1990. Effective-medium theory of sedimentary rocks. Physical Review B 41, 4507.

Sheng, P., 1991. Consistent modeling of the electrical and elastic properties of sedimentary rocks. Geophysics 56, $1236-1243$.

Singh, S.C., Minshull, T.A., Spence, G.D., 1993. Velocity structure of a gas hydrate reflector. Science 260, $204-207$.

Smith, A.J., Flemings, P.B., Liu, X., Darnell, K., 2014. The evolution of methane vents that pierce the hydrate stability zone in the world's oceans. J. Geophys. Res. 119, 6337-6356.

Sultan, N., Marsset, B., Ker, S., Marsset, T., Voisset, M., Vernant, A.M., Bayon, G., Cauquil, E., Adamy, J., Colliat, J., et al., 2010. Hydrate dissolution as a potential mechanism for pockmark formation in the Niger delta. J. Geophys. Res. 115.

Te Wu, T., 1966. The effect of inclusion shape on the elastic moduli of a two-phase material. International Journal of solids and structures 2, 1-8. Telford, W.M., Geldart, L.P., Sheriff, R.E., 1990. Applied geophysics, Cambridge University Press. volume 2nd. ed., pp. i-iv.

Torres, M., Trehu, A.M., Cespedes, N., Kastner, M., Wortmann, U., Kim, J.H., Long, P., Malinverno, A., Pohlman, J., Riedel, M., et al., 2008. Methane hydrate formation in turbidite sediments of northern Cascadia, IODP Expedition 311. Earth Planet. Sci. Lett. 271, 170-180.

Vaular, E.N., Barth, T., Haflidason, H., 2010. The geochemical characteristics of the hydrate-bound gases from the Nyegga pockmark field, Norwegian Sea. Organic Geochemistry 41, 437-444.

Weaver, P., Schultheiss, P., 1990. Current methods for obtaining, logging and splitting marine sediment cores. Mar. Geophys. Res. 12, 85-100.

Weber, M.E., Niessen, F., Kuhn, G., Wiedicke, M., 1997. Calibration and application of marine sedimentary physical properties using a multi-sensor core logger. Mar. Geol. 136, 151-172.

Weitemeyer, K., Constable, S., Key, K., Behrens, J., 2006. First results from a marine controlled-source electromagnetic survey to detect gas hydrates offshore Oregon. Geophys. Res. Lett. 33. doi 10.1029/2005GL024896

Westbrook, G., Chand, S., Rossi, G., Long, C., Bünz, S., Camerlenghi, A., Carcione, J., Dean, S., Foucher, J.P., Flueh, E., et al., 2008a. Estimation of gas hydrate concentration from multi-component seismic data at sites on the continental margins of NW Svalbard and the Storegga region of Norway. Mar. Petrol. Geol. 25, 744-758.

Westbrook, G.K., Exley, R., Minshull, T., Nouzé, H., Gailler, A., et al., 2008b. High-resolution 3D seismic investigations of hydrate-bearing fluid- 
escape chimneys in the Nyegga region of the Vøring plateau, Norway, in: Proceedings of the 6th International Conference on Gas Hydrates (ICGH 2008), Vancouver, BC, Canada, July 6-10, 2008.

Wood, W., Lindwall, D., Gettrust, J., Sekharan, K., Golden, B., 2000. Constraints on gas or gas hydrate related wipeouts in seismic data through the use of physical models. Eos (Transactions, American Geophysical Union) 81, F639.

Yoneda, J., Masui, A., Konno, Y., Jin, Y., Kida, M., Katagiri, J., Nagao, J., Tenma, N., 2017. Pressure-core-based reservoir characterization for geomechanics: Insights from gas hydrate drilling during 2012-2013 at the eastern Nankai Trough. Mar. Petrol. Geol. 86, 1-16.

Zhang, H., Yang, S., Wu, N., Su, X., Holland, M., Schultheiss, P., Rose, K., Butler, H., Humphrey, G., 2007. Successful and surprising results for China's first gas hydrate drilling expedition, US Department of Energy, Office of Fossil Energy, National Energy Technology Laboratory 7, 6-9.

3 Zhong, G., Liang, J., Guo, Y., Kuang, Z., Su, P., Lin, L., 2017. Integrated core-log facies analysis and depositional model of the gas hydrate-bearing sediments in the northeastern continental slope, South China Sea. Mar. Petrol. Geol. 86, 1159-1172. 
Table 1: Main lithofacies units of the background and CNE03 sediment cores.

\begin{tabular}{|c|c|c|c|c|}
\hline Lithofacies & Description & Boundaries & $\overline{\text { Units }^{a}}$ & Interpretation \\
\hline 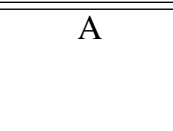 & $\begin{array}{l}\text { Medium grained muddy sands orange brown in } \\
\text { colour, rich in foraminifera }\end{array}$ & $\begin{array}{ll}\text { Undulating } & \text { lower } \\
\text { boundary, } & \text { upper } \\
\text { surface at core top }\end{array}$ & $\overline{\overline{B G 1}}$ & $\begin{array}{l}\text { Winnowed } \\
\text { Holocene sands }\end{array}$ \\
\hline B & $\begin{array}{l}\text { Pale brown-grey brown silts. Variable con- } \\
\text { tent of ice-rafted debris, occasional blebs } \\
\text { of tephra and abundant planktic and benthic } \\
\text { foraminifera. Units are distinguished by vari- } \\
\text { able amounts of bioturbation visible as oxi- } \\
\text { dised burrows }\end{array}$ & Indistinct, non-erosive & BG2-BG10 & $\begin{array}{l}\text { Hemipelagic } \\
\text { diamicton }\end{array}$ \\
\hline $\mathrm{C}$ & $\begin{array}{l}\text { Pale green-grey, fine grained muds. } \\
\text { Foraminifera present, some of large size. } \\
\text { No visible laminations or sedimentary struc- } \\
\text { tures, patches of orange-brown staining and } \\
\text { cavities of variable size. Clathrate recovered } \\
\text { from this lithofacies onboard }\end{array}$ & $\begin{array}{l}\text { None visible, grades } \\
\text { into lithofacies D }\end{array}$ & $\begin{array}{l}\text { CN1, CN3, } \\
\text { CN5 }\end{array}$ & $\begin{array}{l}\text { Altered } \\
\text { hemipelagic } \\
\text { and pockmark } \\
\text { ooze. Along CN5 } \\
\text { there are cavities, } \\
\text { indicating the } \\
\text { dissociation of } \\
\text { hydrate clathrates. } \\
\text { Tephra bleb } \\
\text { observed in CN5. }\end{array}$ \\
\hline $\mathrm{D}$ & $\begin{array}{l}\text { Shell horizon of intact chemosynthetic Isor- } \\
\text { ropodon bivalve. X-rays reveal articulated } \\
\text { shells, some carbonate nodules present (up to } \\
3 \mathrm{~cm} \text { ) }\end{array}$ & $\begin{array}{l}\text { Diffuse, concentration } \\
\text { of shells gradually in- } \\
\text { creases and decreases } \\
\text { within surrounding } \\
\text { sediments }\end{array}$ & $\mathrm{CN} 2, \mathrm{CN} 4$ & $\begin{array}{l}\text { Presence of } \\
\text { chemosynthetic } \\
\text { biota, indicative to } \\
\text { free gas fluxes and } \\
\text { hydrate formation }\end{array}$ \\
\hline
\end{tabular}

${ }^{a}$ BG units $=$ Background sediment, $\mathrm{CN}$ units $=\mathrm{CNE} 03$ sediment. 
Table 2: X-ray diffraction (XRD) for semi-quantitative bulk analysis of the individual minerals that form the CNE03 sediments ${ }^{a}$.

\begin{tabular}{cc}
\hline Mineral & Quantity (per cent) \\
\hline Clay & 55 \\
Quartz & 17.5 \\
Calcite & 8 \\
Magnesium Calcite $^{b}$ & 8.2 \\
K-feldspar & 3.6
\end{tabular}

${ }^{a}$ The sediment sample for XRD was obtained from the CNE03 core at $\sim 6$ mbsf.

${ }^{b}$ Magnesium Calcite is indicative of biogenic activity. 
Table 3: Physical properties of the constituents used in the SCA/DEM effective medium models.

\begin{tabular}{|c|c|c|c|c|c|}
\hline Constituent & $K(\mathrm{GPa})$ & $\mu(\mathrm{GPa})$ & $\rho(\Omega \mathrm{m})$ & $d\left(\mathrm{~g} \mathrm{~cm}^{-3}\right)$ & References \\
\hline Quartz & 36.6 & 45 & $10^{5}$ & 2.65 & Mavko et al. (1998); Han et al. (2011a) \\
\hline Clay & 20.9 & 6.85 & 33 & 2.58 & Mavko et al. $(1998) ;$ Han et al. (2011a) \\
\hline$C Q \operatorname{mix}^{a}$ & 26.7 & 15.63 & 95 & 2.61 & Computed \\
\hline Brine & 2.29 & 0 & 0.185 & 1.025 & Telford et al. (1990), and Computed $\rho$ \\
\hline Hydrate & 7.9 & 3.3 & 200 & $0.925 \mathrm{C}$ & Goldberg et al. (2000); Best et al. (2013) \\
\hline
\end{tabular}

* $K=$ Bulk modulus, $\mu=$ Shear modulus.

$* \rho=$ Resistivity, $d=$ Density.

${ }^{a}$ Clay+Quartz (CQ) mix, containing $55 \%$ clay and $45 \%$ quartz. 


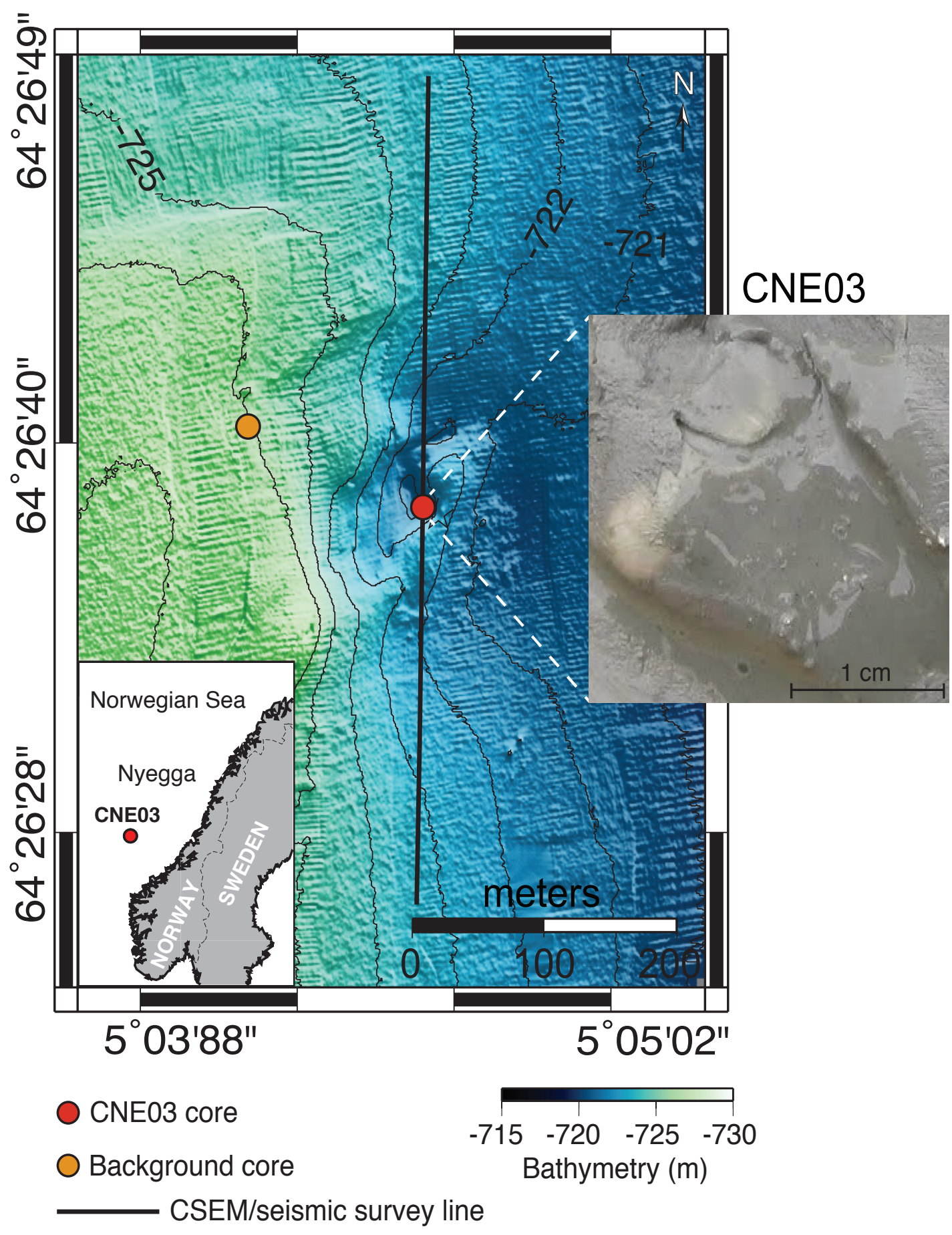

Figure 1: Bathymetry of the CNE03 pockmark area (Attias et al. 2016, showing sediment core locations. The black line represents coincident CSEM and seismic surveys. Inset map: location of the CNE03 pockmark, Nyegga region, offshore Norway. Right image: hydrates (white areas) observed in the sediment core retrieved from within the CNE03 pockmark. Note the presence of gas bubbles, resulting from the dissociation of hydrate consequently to unpressurized core recovery. 


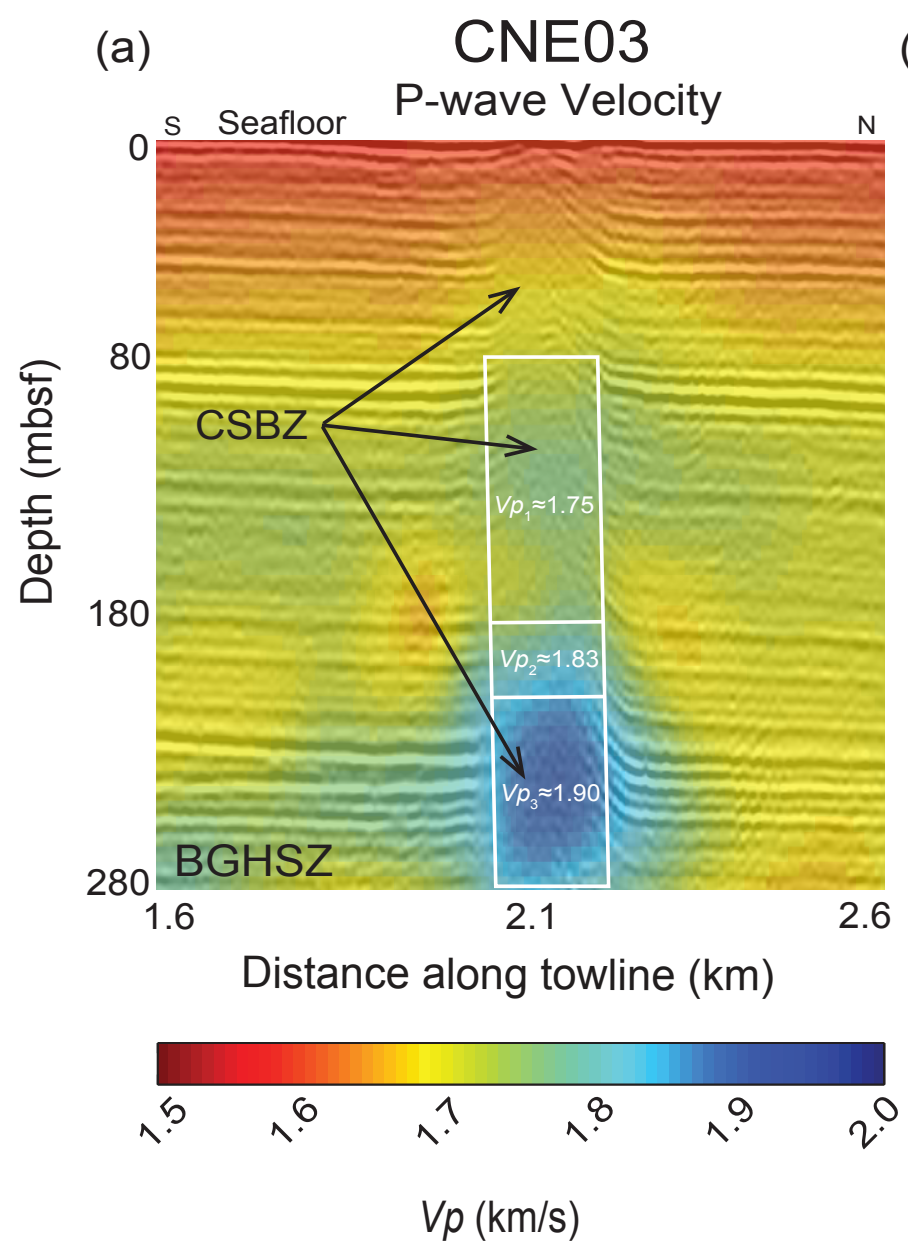

(b)
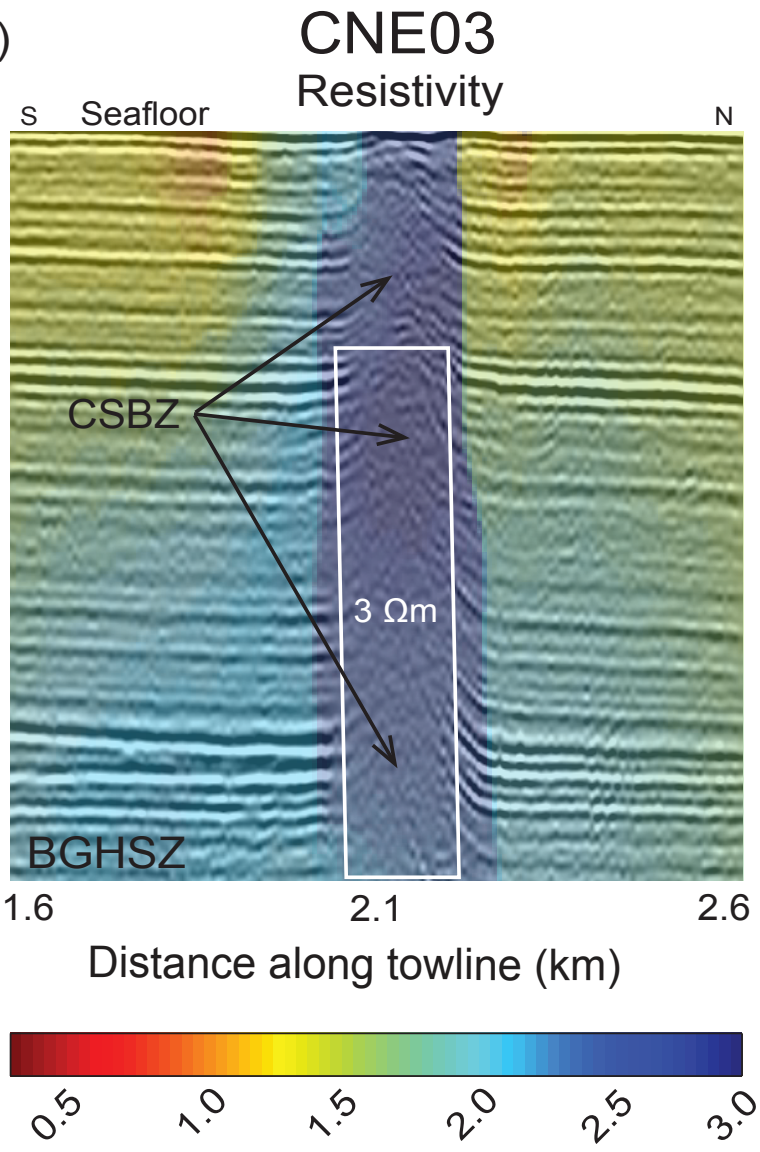

Resistivity $(\Omega m)$

Figure 2: (a) Seismic velocity and (b) resistivity models obtained from south to north profile (Fig. 11), co-rendered with 2-D high-resolution seismic reflection section (modified from Attias et al. (2016)). White rectangles bound the area for which $V_{P}$ and resistivity data were averaged and extracted for comparison with the effective medium model. The $V_{P}$ data was divided into three distinctive velocity regions. Black arrows denote the columnar seismic blanking zone (CSBZ) observed in seismic reflection data throughout the CNE03 pipe-like structure. The seismic reflection profile was acquired using a GI-gun source and seismic streamer with three $25 \mathrm{~m}$ long active sections, carrying 37 hydrophones each (Westbrook et al. 2008b). The CSEM data was collected using the University of Southampton CSEM system, as described by Attias et al. (2016). 
(a)

(b) (c)

Legend

\section{Background Core

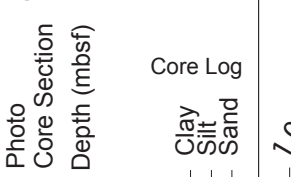 \\ Background/CNE03 cores and samples data Resistivity \\ - \\ P-wave velocity $(\mathrm{km} / \mathrm{s})$}

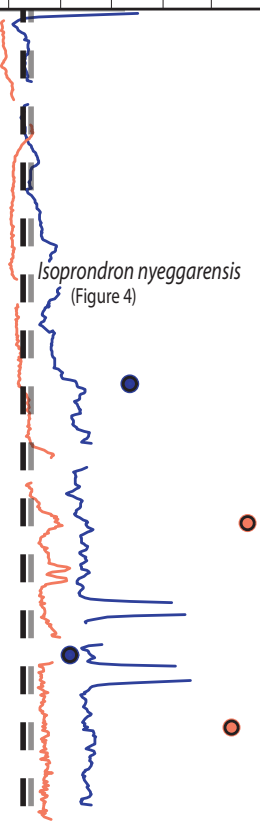

II

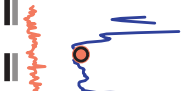

II妾

I)

II

II

II

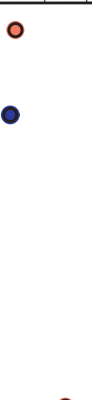<smiles>C1CCCCCCCCCC1</smiles>

CNE03 Core

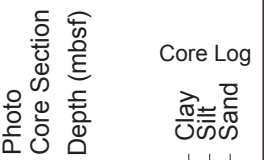

Cavity - whole core diameter

Oxidation stain

$\ddot{\sim} \approx$ Burrows (Large)

Areas of transition between core sections - No measurements

Bioturbation - small burrows

$\therefore$ Methanotrope shell horizon

- Tephrableb

$\square$ Holocene winnowed sands

BG \& CN units - Lithofacies (see Table 2)

\section{Macro-scale Measurements (MSCL-S)} Background core resistivity CNEO3 core resistivity

Background core P-wave velocity CNEO3 core P-wave velocity

Background core Porosity CNEO3 core Porosity

\section{- CNEO3 core Porosity}

Meso-scale Measurements (ERT)

- Background samples resistivity

- CNE03 samples resistivity * Measurment accuracy $\pm 5 \%$

- Background samples P-wave velocity

- CNE03 samples P-wave velocity * Measurment accuracy $\pm 0.3 \%$

- Background samples porosity

- CNE03 samples porosity * Measurment accuracy $\pm 5 \%$

Micro-scale Samples (X-CT)

- Samples for X-CT scans (not to scale)

- - - . Values used for SCA/DEM model calibration based on seismic and CSEM background sediment results

" - - " Background core resistivity, Vp and porositiy averaged values (from consitent sections

Figure 3: Characterisation of the background and CNE03 sediment cores, using images, petrophysical measurements using MSCL-S, and visual logging. The lateral distance between the locations of these cores is approximately $150 \mathrm{~m}$. (a) Background sediment core lithology. (b) Macroand meso- scale resistivity, porosity and $V_{P}$ measurements. Gaps in the background macro-scale resistivity measurement represent the transitions between core sections. The sharp resistivity peaks in the CNE03 macro-scale measurement are associated with cavities, presumably caused by the dissociation of hydrates. Core locations of the samples extracted for the ERT analysis (section 4.2) are denoted. (c) CNE03 sediment core lithology. Isorropodon nyeggaensis sp. shell fragments were found within the CNE03 sediment core samples (Fig. 4). 


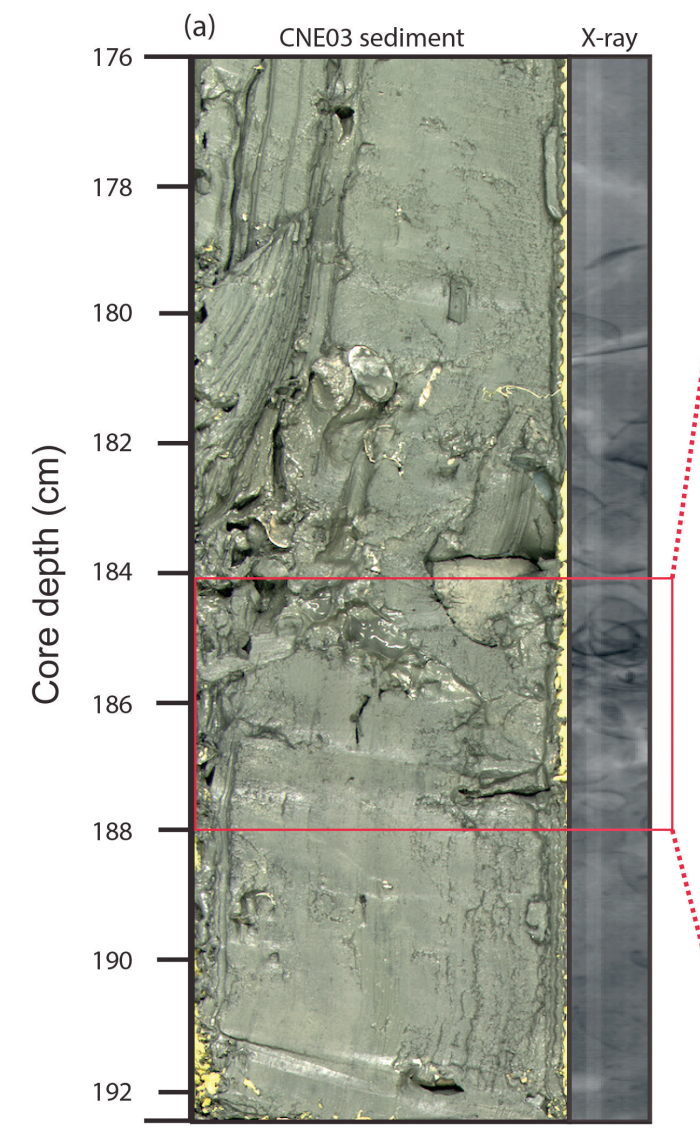

(b) X-ray:zoom-in

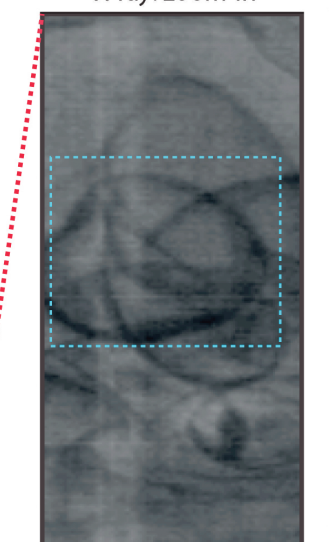

(c)

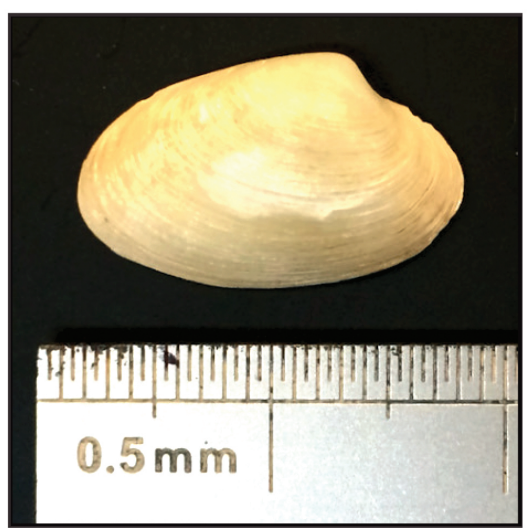

(d)

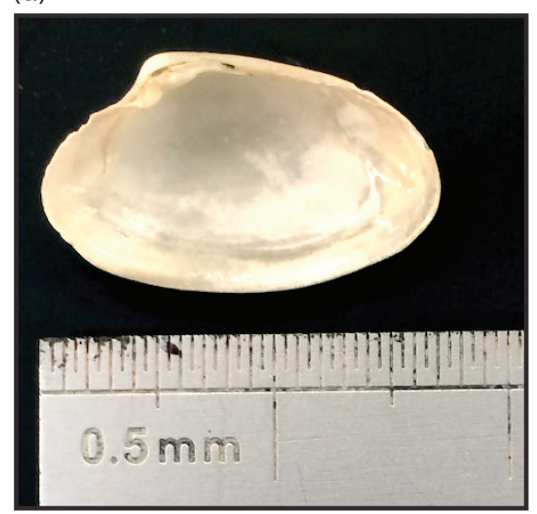

Figure 4: CNE03 core section X-ray analysis. (a) Sediment image and a close-up X-ray image of the core section between 176-192 cm core depth (taken using the ITRAX core scanner spanning the central $2 \mathrm{~cm}$ of the core). Red rectangle denotes the region from the X-ray image that was enlarged. (b) Zoomed-in X-ray image. Blue rectangles denote the presence of intact and articulated bivalves, which indicates deposition in-situ or with minimal reworking. Extracted and cleaned valve of species identified as the chemosynthetic Isorropodon nyeggaensis sp. bivalves, shown with left exterior view (c) and left interior view (d). These dead Isorropodon nyeggaensis sp. bivalves might indicate a cut-off in methane gas supply (due to hydrate formation), which is essential for their metabolism (e.g., Cavanaugh 1983). 
(a)

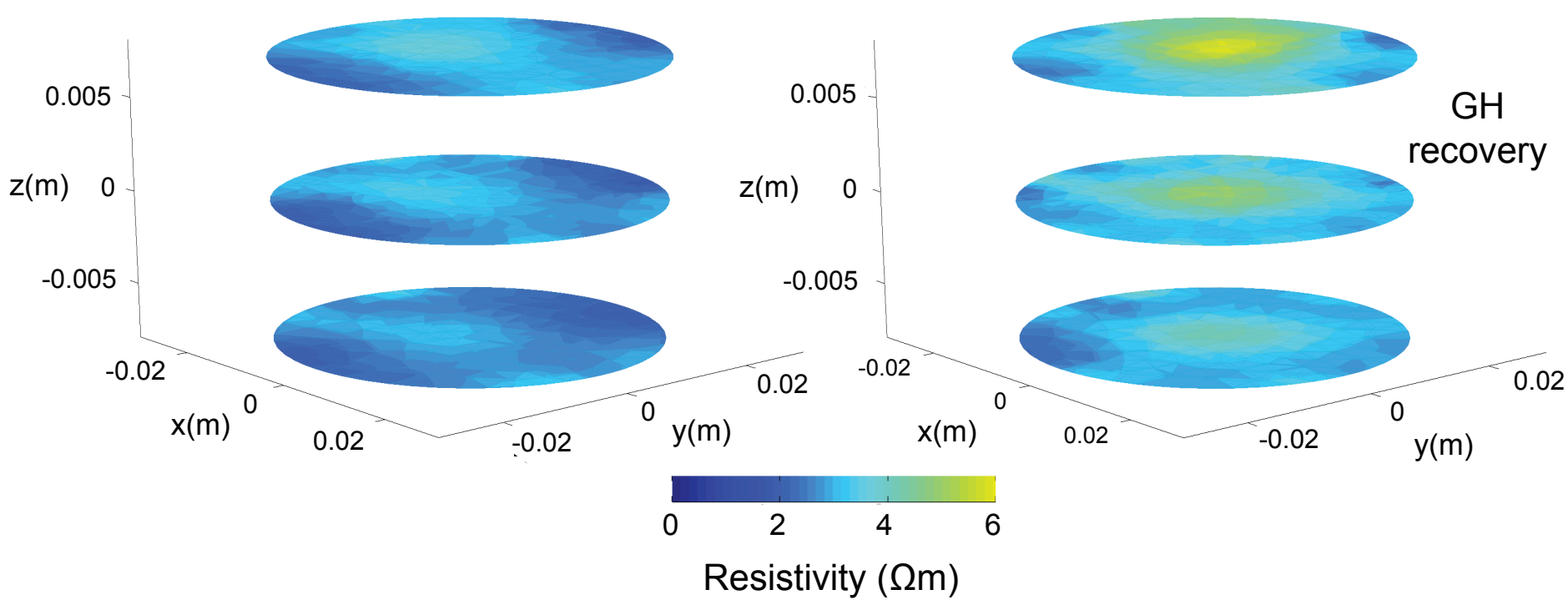

Figure 5: Electrical resistivity tomography (ERT). (a) Three transverse ERT images through the background core sample obtained from $\sim 6.8$ mbsf (Fig. 3a, core section A). (b) Three transverse ERT images through the CNE03 core sample obtained from $\sim 6.5$ mbsf, in proximity to the location of gas hydrate recovery (Fig. 33, core section A). Note that the resistivity colour scale is inverse to the one presented in Fig. 2 p. The background sample resistivity agrees well with the resistivity obtained from the macro-scale core measurement. The CNE03 relatively high resistivity is most likely related to pore-water freshening (due to hydrate dissociation) and the presence of resistive shells. 
(a)

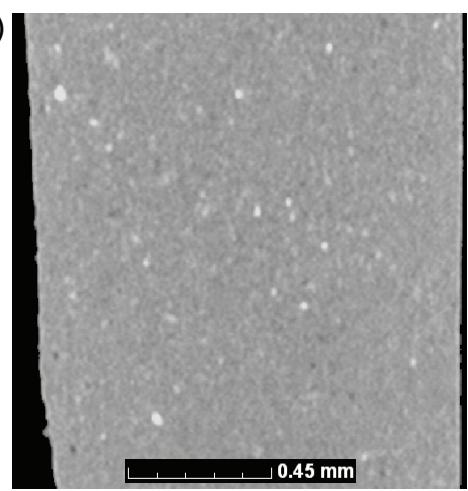

(b)

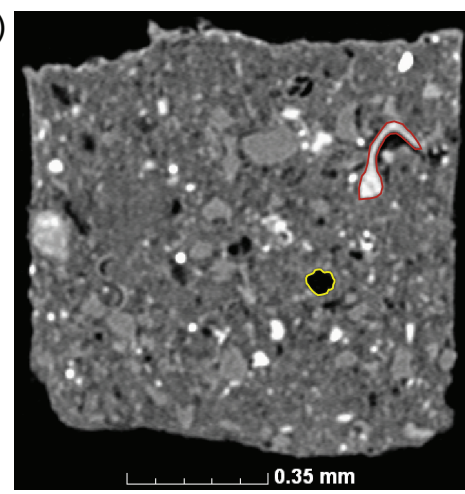

(c)

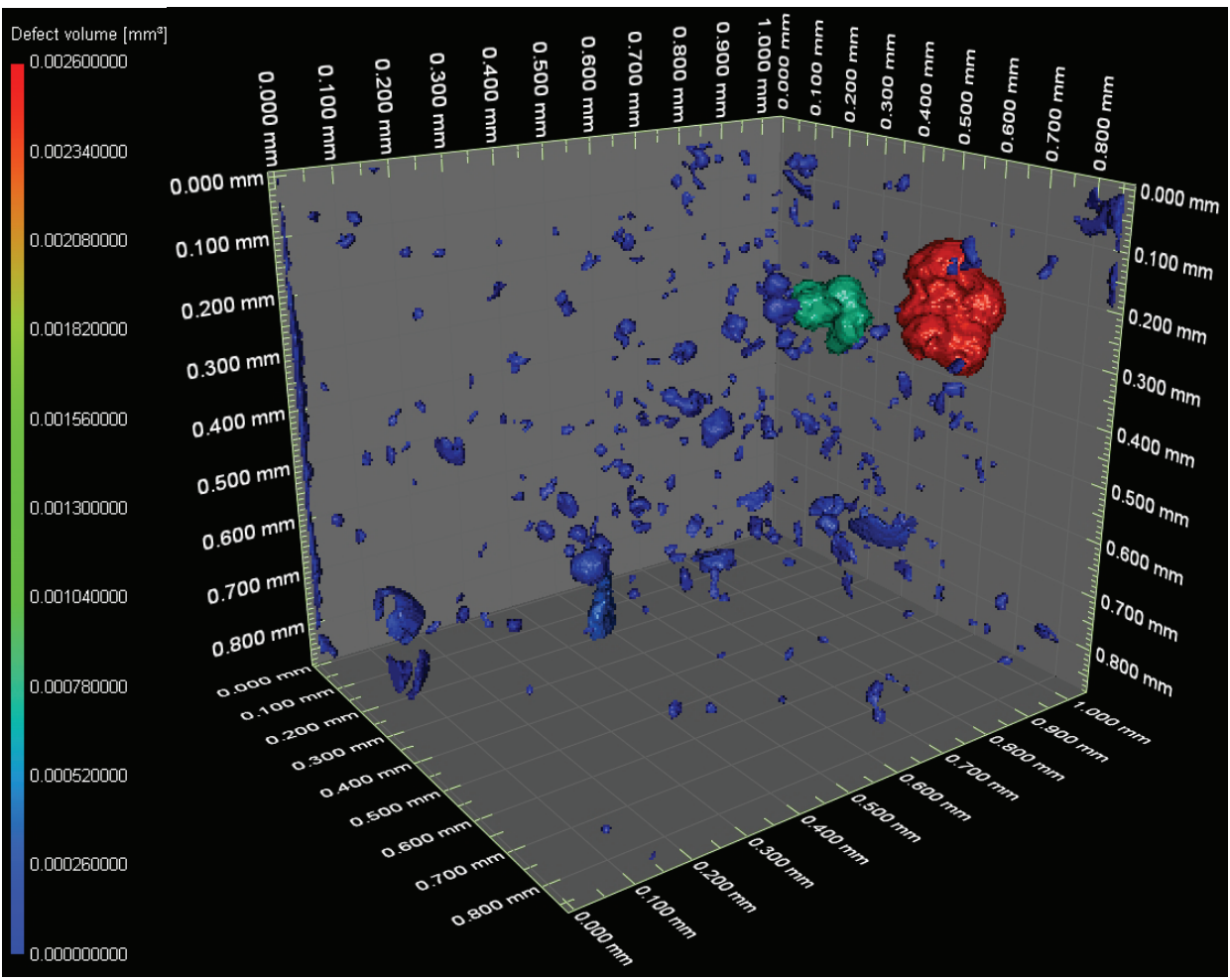

Figure 6: X-CT scans of micro-scale samples obtained from the background and CNE03 cores, approximately 0.5 mbsf. (a) Side view of the background sample. (b) Side view of the CNE03 sample. The red colour outlines a fragment of the Isorropodon nyeggaensis sp. chemosynthetic shell. The yellow colour outlines foraminifera. (c) 3-D view showing the pore volume $\left(\mathrm{mm}^{3}\right)$ distribution within the CNE03 sample. The blue colour represents the overall pore size ( $\sim 0.001-0.05 \mathrm{~mm}$ in length), the green colour shows the intermediate pore size ( $\sim 0.1 \mathrm{~mm})$, and the red colour denotes the largest pore size $(\sim 0.2 \mathrm{~mm})$. Note that the X-CT resolution is not high enough the observe the grain contacts or pores that are smaller than 4 micron, due to the clay-rich sediment. 
(a)

2-phase SCA/DEM (model calibration)

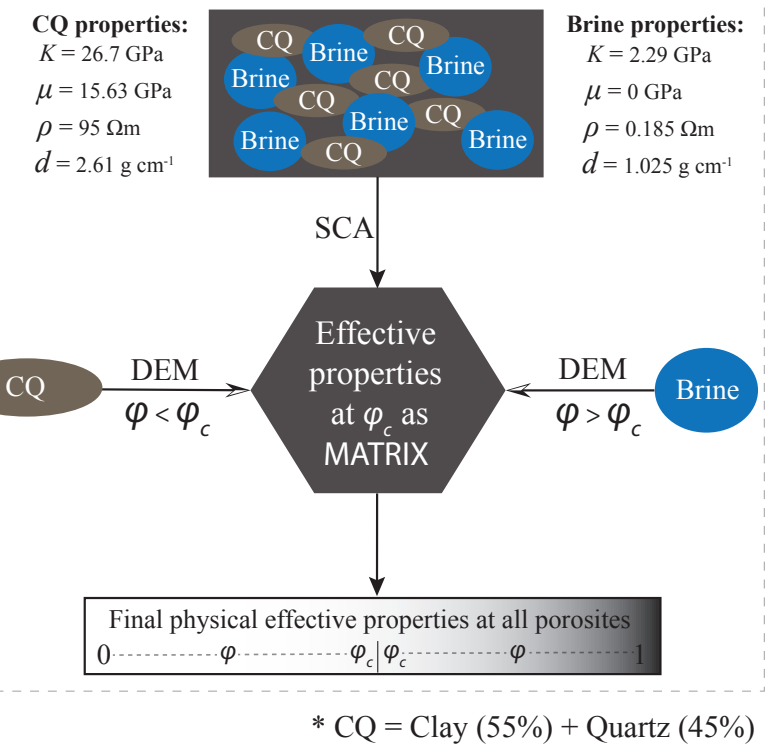

(b)

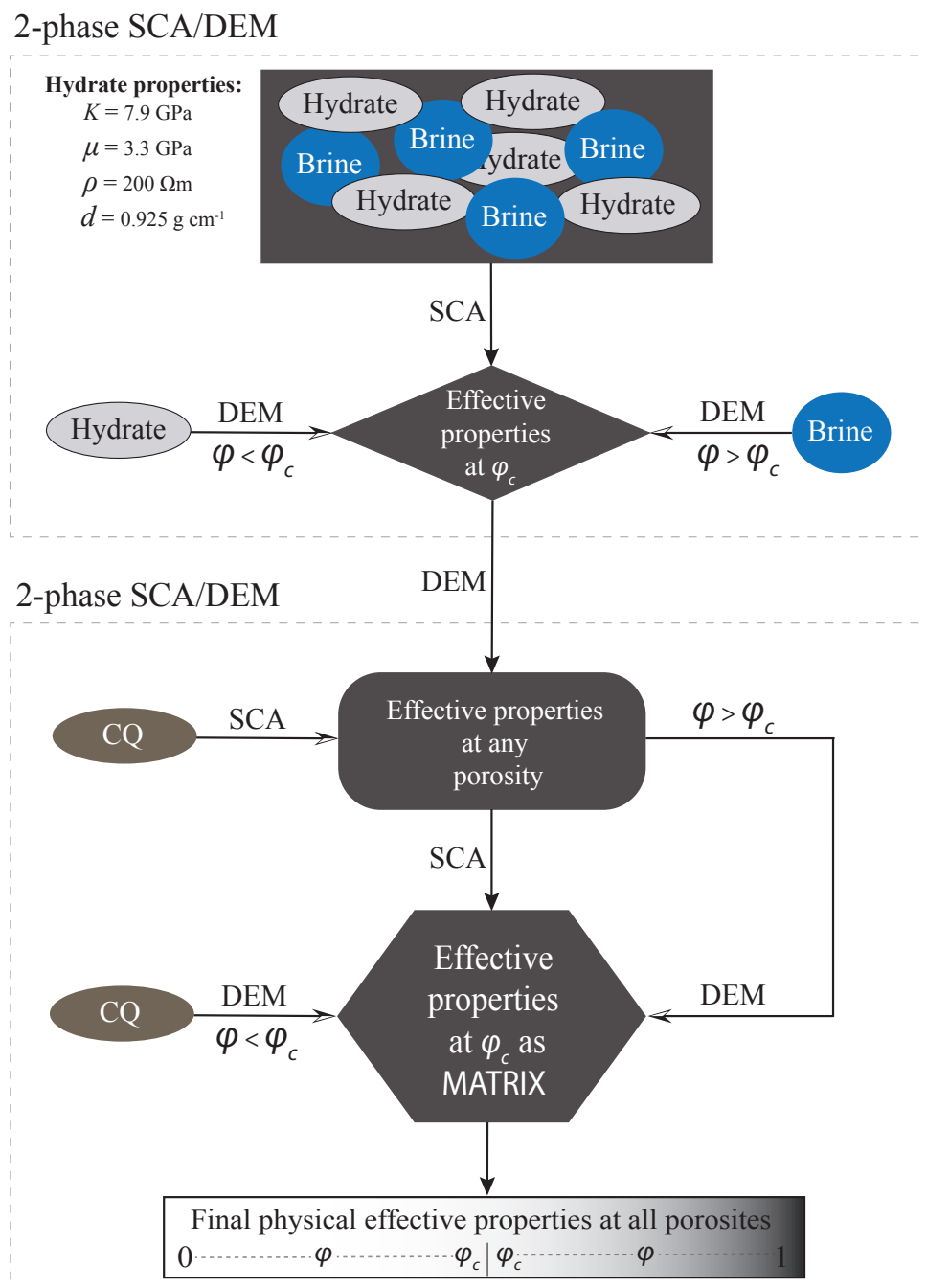

Figure 7: Combined self-consistent approximation (SCA)/differential effective medium (DEM) modelling steps applied to model both elastic and electrical properties. (a) Schematic diagram showing the implementation of a two-phase SCA/DEM model for $C Q$ mix (clay+quartz) and brine. (b) Schematic diagram showing the implementation of a three-phase SCA/DEM model for pore-filling hydrate in clay-rich (CQ mix) marine sediments. Note that the implementation of the biconnected three-phase is achieved by applying the two-phase approach twice. The physical parameters of the inclusions used at each modelling step are listed. $K$ is the bulk modulus, $\mu$ is the shear modulus, $\rho$ is resistivity, and $d$ is density. Porosity is denoted by $\varphi$. All model steps employed an aspect ratio of 0.2 and a critical porosity $\left(\varphi_{c}\right)$ of 0.6 . Grayscale gradient represents increasing porosity. Adapted from Han et al. (2011a). 
(a)

Two-phase SCA/DEM model calibration

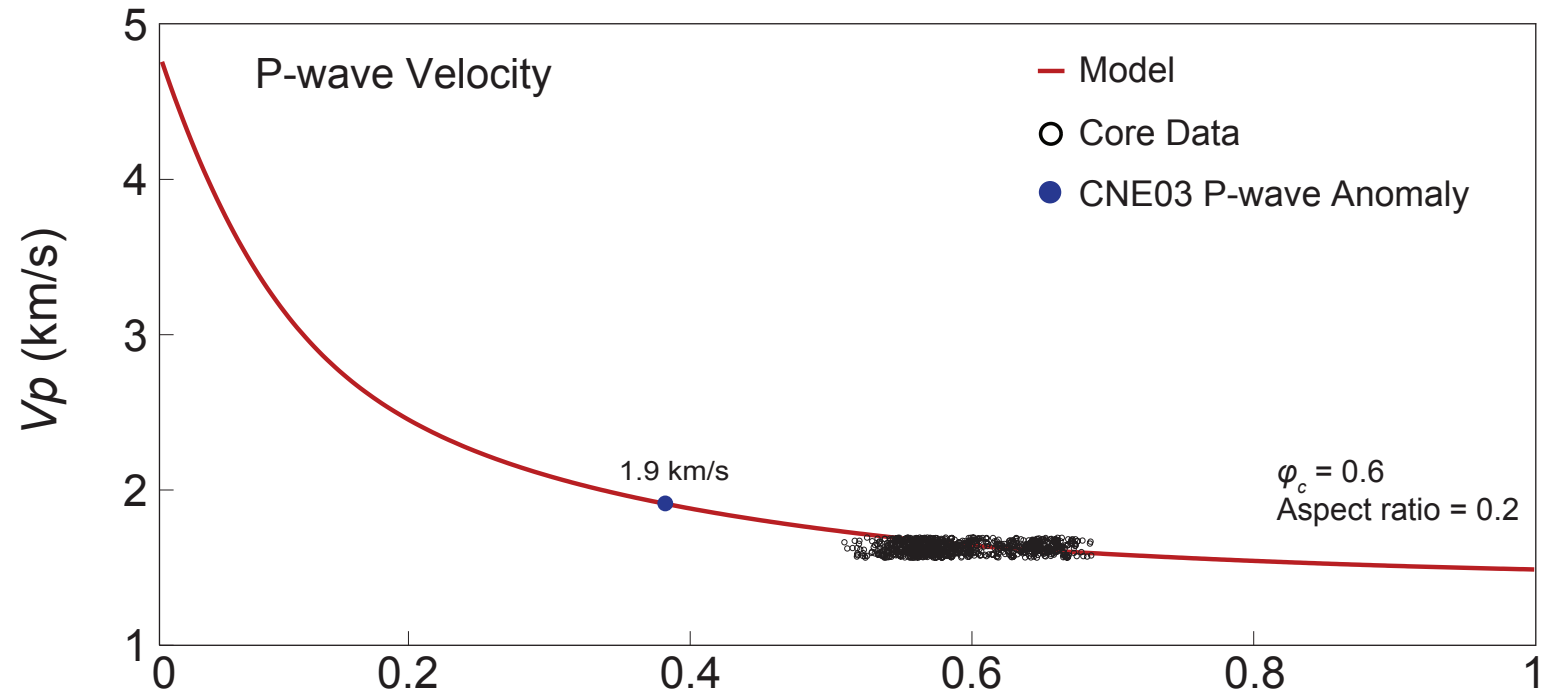

(b)

Porosity

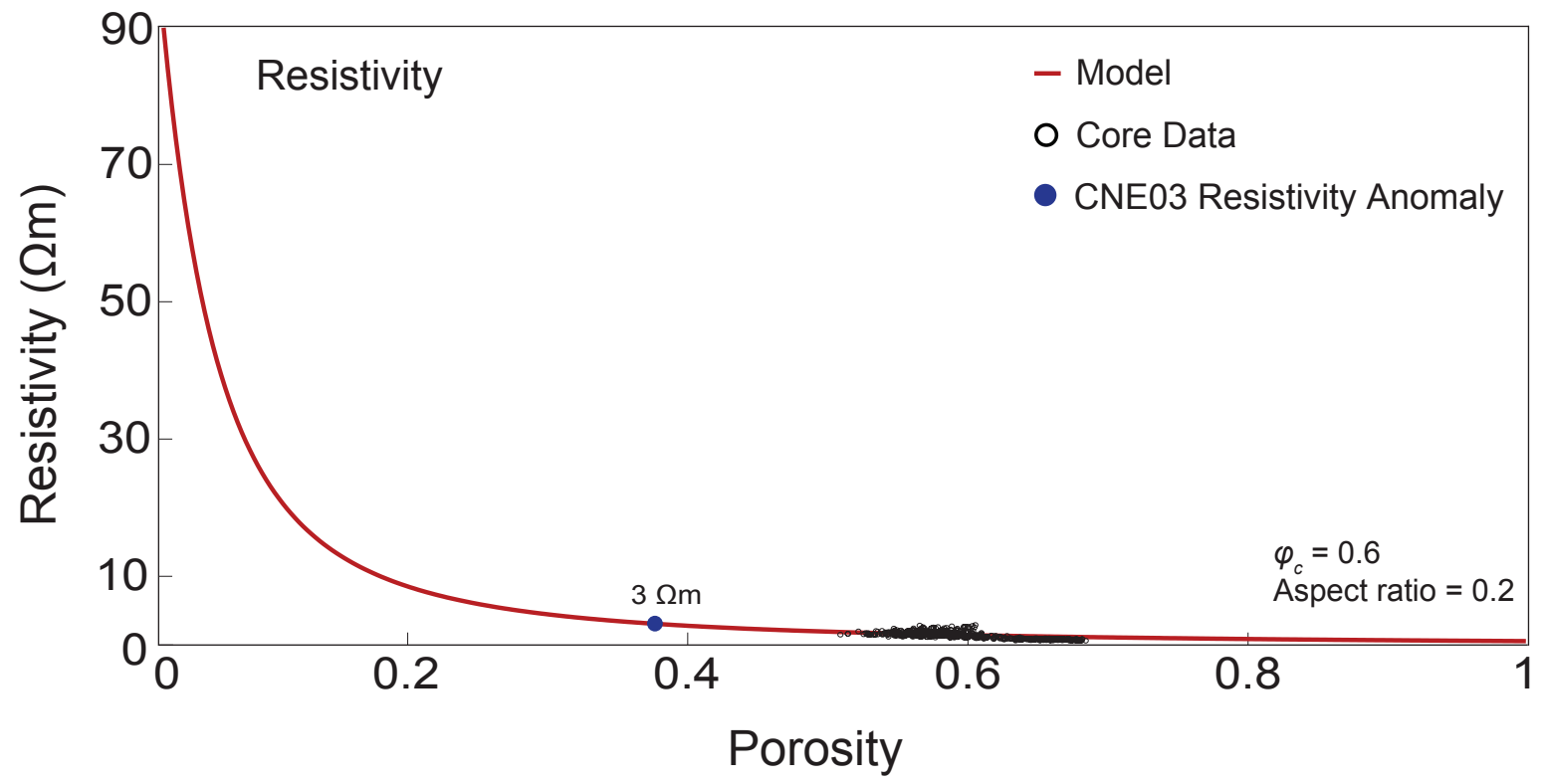

Figure 8: Two-phase SCA/DEM model calibration. The red curves show the model calibrated to the $V_{P}$ and resistivity values extracted vertically from the seismic and CSEM datasets, $\sim 150 \mathrm{~m}$ north to the CNE03 pipe-like structure. The Blue dots denote the anomalous $V_{P}$ and resistivity values observed within the CNE03 pipe-like structure, between $\sim 200-280 \mathrm{mbsf}$ (Fig. 2). Note that these anomalous values correspond to a low porosity of $\sim 0.38$, which is an unfeasible porosity for an hydrate-free zone at Nyegga. Thus, indicate that the measured $V_{P}$ and resistivity anomalies are most likely caused by the presence of hydrates rather than an increase in effective stress (section 5.2). The calibrated curves are superimposed by black circles that represent the data obtained from the macro-scale background core measurements (Fig. 3p). The two-phase model contains the $C Q$ mix (phase 1) and brine (phase 2). (a) $V_{P}$ vs porosity (b) Resistivity vs porosity. The $V_{P}$ and resistivity data obtained from the background core (Fig. 3p) are in good agreement with the calibrated model. 


\section{Three phase joint elastic-electrical SCA/DEM model}

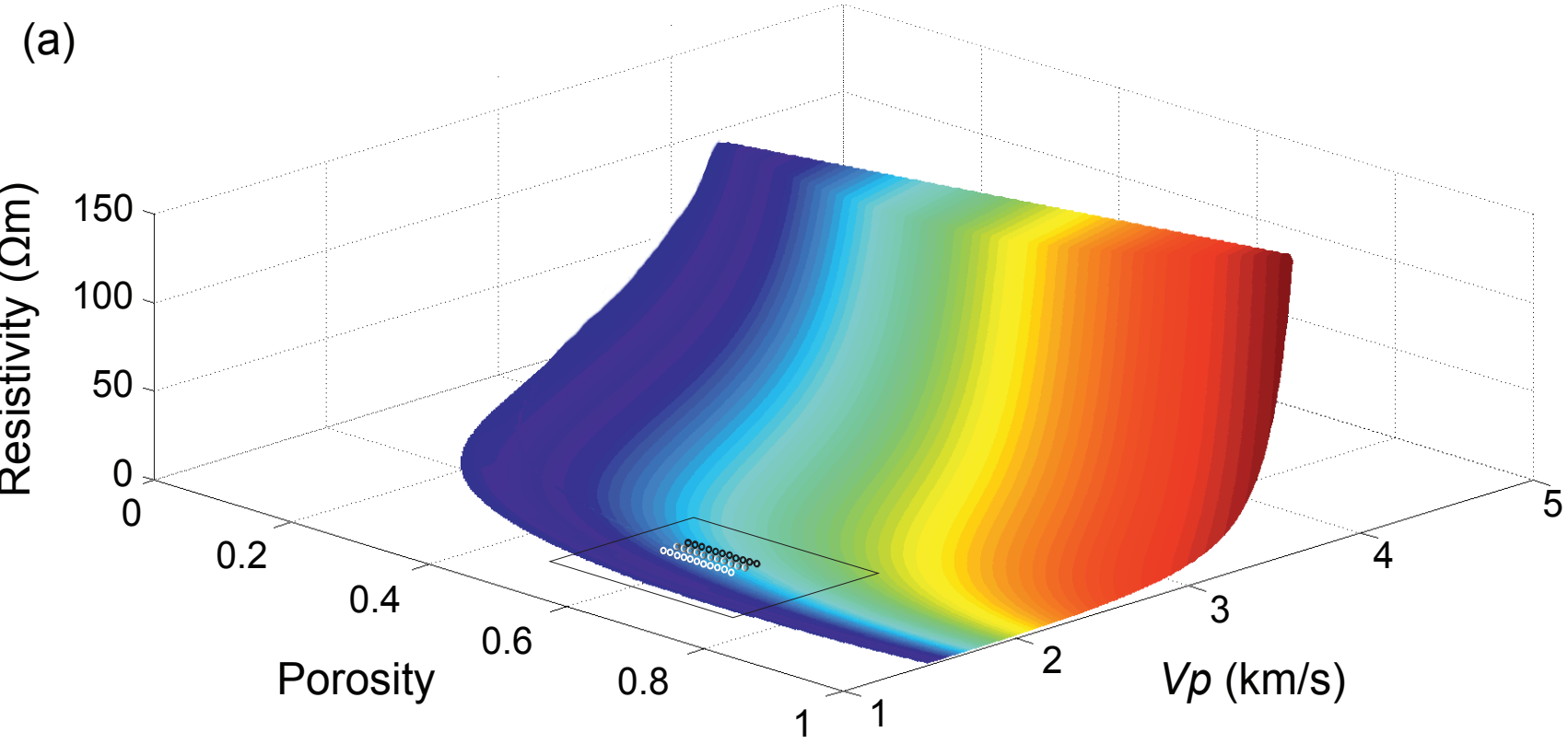

(b)

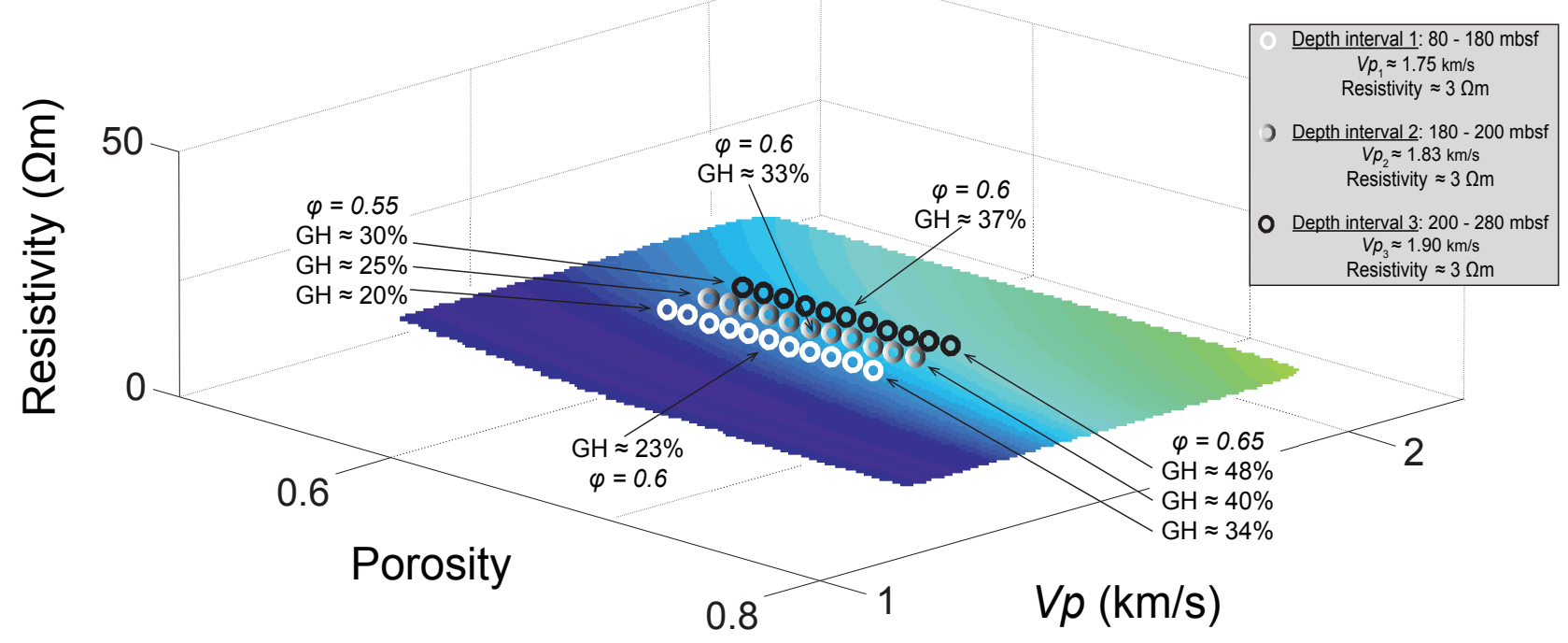

Gas hydrate content
0.1
0.3
0.5
0.7
0.9

Figure 9: Comparison of the joint elastic-electrical properties obtained from the combined self-consistent approximation (SCA)/differential effective medium (DEM) model with CSEM and seismic remote sensing data. (a) Three phase SCA/DEM model illustrate changes in gas hydrate (GH) content as a function of varying porosity $(\varphi)$, electrical resistivity and seismic velocity. Note that the models are colour-coded by volumetric gas hydrate content. Values extracted from the seismic and CSEM data (Fig. 2) overlay the effective medium model. (b) Expanded image from (a), showing the hydrate estimates from the three sets of $V_{P}$-resistivity pairs for a narrower porosity range. These three sets of values ( $V_{P}$ dependent) are denoted by white, white-black gradient, and black circles, for a porosity range of $0.55-0.65$. 